\title{
A Review of Renewable Energy Options, Applications, Facilitating Technologies and Recent Developments
}

\author{
Seama Koohi-Fayegh ${ }^{1 \star}$, Marc A. Rosen ${ }^{1}$
}

${ }^{1}$ Faculty of Engineering and Applied Science, University of Ontario Institute of Technology, 2000 Simcoe Street North, Oshawa, Ontario, L1G 0C5, CANADA *Corresponding Author: seama.koohi@ontariotechu.ca

Citation: Koohi-Fayegh, S. and Rosen, M. A. (2020). A Review of Renewable Energy Options, Applications, Facilitating Technologies and Recent Developments. European Journal of Sustainable Development Research, 4(4), em0138. https://doi.org/10.29333/ejosdr/8432

\begin{tabular}{ll}
\hline ARTICLE INFO & $\begin{array}{l}\text { ABSTRACT } \\
\text { Received: } 20 \text { May } 2020\end{array} \quad \begin{array}{l}\text { A critical overview of renewable energy is provided, including descriptions of renewable energy sources, } \\
\text { technologies, assessments, comparisons and planning as well as energy technologies that facilitate renewable } \\
\text { energy sources. The renewable energy types considered include solar, wind, geothermal, bioenergy and waste- } \\
\text { derived energy, ocean thermal energy, tidal, wave and hydraulic. Also covered for contextual and broader } \\
\text { purposes are energy systems more generally and their sustainability. In addition, recent research on new } \\
\text { renewable energy sources as well as important recent developments in renewable energy are considered. }\end{array}$
\end{tabular}

Keywords: renewable energy, status review

\section{INTRODUCTION}

Sunlight and heat from the sun are converted and received in the ambient environment in a number of ways, resulting in fossil fuels and renewable energy flows. For a long time, fossil fuels constituted the main energy source used by societies worldwide. However, fossil fuel reserves are decreasing over time and their utilization leads to pollution that harms ecosystem and human health and greenhouse gas (GHG) emissions that are linked to global warming. Therefore, it is generally believed that there is a need for the creation, development, and deployment of plans for large-scale and carbon-neutral production of energy that meet present and future energy needs. This almost certainly involves substituting fossil fuels with alternative energy sources. Renewable energies and nuclear energy are promising replacements to fossil fuels that could meet humanity's energy needs sustainably and, in particular, without causing extensive damage to the environment.

The status for electricity generation of various renewable energy types, such as solar, wind, hydraulic, biomass, ocean and geothermal, is frequently reported and the development potentials of renewable energies are often investigated (Bouraiou et al., 2020; Kuang et al., 2016; Østergaard et al., 2020). The development of renewable energy sources includes integration of various sources to into hybrid systems, sometimes linked to electrical grids, and has resulted in studies on optimal sizing, energy management (Chamandoust et al., 2020), operating and control strategies (Shivarama Krishna and Sathish Kumar, 2015). While a promising option for climate change mitigation, challenges exist that lessen renewable energy resource sustainability and various measures and policies are needed to realize their potentials (Owusu and Asumadu-Sarkodie, 2016). Past reviews are usually limited regarding the types of renewable energy considered. For instance, some reviews are directed at a single renewable energy topic such as reviews on wind energy or on multiple types of renewable energy for single applications like centralized power generation. Other reviews aim at renewable energy types but exclude technologies that are integrated to facilitate the utilization of renewable energy options like hydrogen energy or thermal energy storage systems. However, more general reviews addressing all renewable energy types and related technologies permit better insights on similarities and differences, potential opportunities for integration, and required developments on policy. Further, as the field of renewable energy is broad with many articles published annually on them from economic, technical and other viewpoint, currency is especially important for reviews intending to review a wide range of topics.

A recent and broad review is provided for each renewable type in the present article. Over 300 articles on all facets of renewable energy were assessed and those deemed the most novel, informative and broad in scope were selected and reviewed. Some published reviews constitute more focused and detailed reviews of a individual renewable energy types or topics, but the present article is different and original, as it gives a broader and more general review of many types of renewable energy, comparing and contrasting their features and characteristics. Consequently, several notable articles may be excluded due to their great level of detail, since they do not fit the scope or purpose of the present review article. 


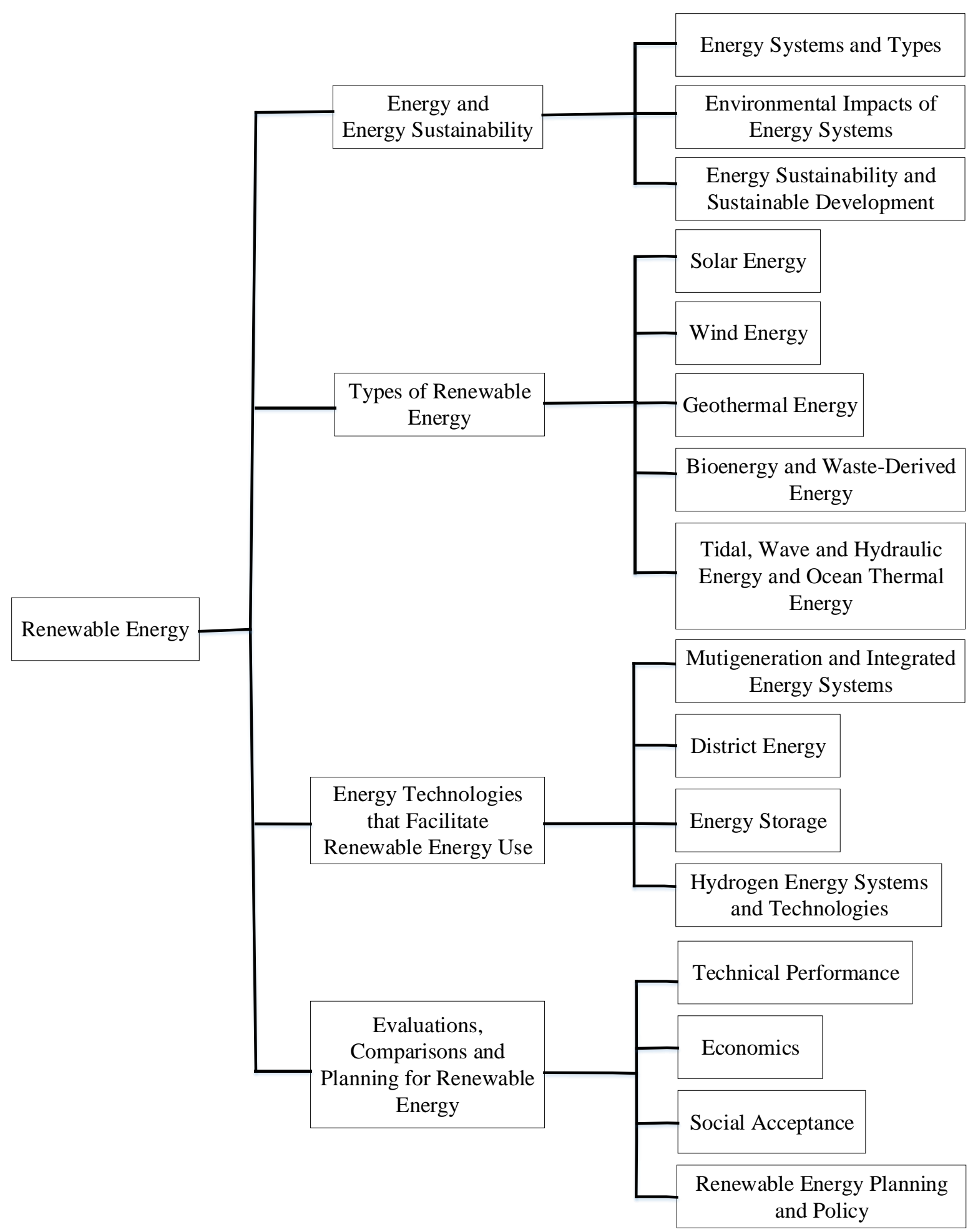

Figure 1. Categorization of renewable energy topic areas in present article

This article provides a critical review and overview of key developments in renewable energy. Renewable energy is reviewed from four perspectives: 1) descriptions of energy systems from a general perspective, focusing on energy sustainability and environmental impacts, 2) examinations of principles, applications and technologies available for each renewable energy type, 3) descriptions and assessments technologies that facilitate renewable energy use (e.g. energy storage), and 4) discussions of evaluations, comparisons, contrasts and planning related to renewable energy options. Throughout, renewable energy research and recent advances are included. Numerous articles on renewable energy are cited in this article, according to such factors as relevance, importance (represented by citation numbers and other factors) and currency. A categorization of renewable energy topics considered in this article is shown in Figure 1. 


\section{ENERGY AND ENERGY SUSTAINABILITY}

Most human activities require energy. Limits to fossil fuel supplies as well as concerns regarding their environment impacts have been the motivation for searches for energy sources that are sustainable in general and environmentally benign in particular.

\section{Energy Systems and Types}

The status of global energy systems and the effect of carbon dioxide emissions from fossil fuels on the global climate (Ayres et al., 2007) is often the main motivation behind the search for alternative energy options. Renewable energies typically include carbon neutral energy sources that mitigate or avoid the environmental impacts of carbon dioxide emissions of fossil fuels and other waste output. Nuclear energy is seen by some as an energy resource that is sustainable, and by others as a non-carbon energy source that can be used to bridge between fossil fuels and renewable energies. Renewable energy sources usually have the potential to be sustainable based on social and economic needs now and in the future. Various energy sources (fossil fuels, nuclear and renewable energies), their challenges and opportunities relating to future global energy supply from such perspectives as sustainability, cost and quality of life are often studied (Armaroli and Balzani, 2007). Rosen (2012) categorises energy sources in terms of natural and additional energy, depending on how the energy is harvested and discusses energy utilization and selection, as well as efficiencies and measures for their improvement.

\section{Environmental Impact of Energy Systems}

Energy resources that are alternatives to fossil fuels often provide opportunities for the mitigation of GHG emissions and the related consequence of climate change. However, when considering these alternatives, other environmental concerns should also be considered, such as resource availability, land use, water quality, wildlife health, chemical emissions, thermal pollution and nuclear-related factors. Several researchers discuss positive and negative effects on the environment of renewable energy (Abbasi and Abbasi, 2012; Asdrubali et al., 2015; Connolly et al., 2016; Desholm and Kahlert, 2005; Fox et al., 2006; Hepbasli, 2008; Hertwich et al., 2015; Inger et al., 2009; International Energy Agency, 2010; Jacobson, 2009; Panwar et al., 2011; Rosen et al., 2008; Stougie et al., 2016; 2018; Tsoutsos et al., 2005).

Hertwich et al. (2015) present an integrated lifecycle assessment (LCA) of carbon dioxide capture and storage in fossil fuel based power generation and of wide-scale and long-term electricity generation from renewable energy resources, i.e., hydropower, solar photovoltaic (PV) and thermal and wind. By contrasting emissions for the business-as-usual and climatechange-mitigation scenarios of the International Energy Agency (2010) to 2050, the authors suggest the climate-change-mitigation as the more suitable option. Although material requirements such as iron for wind power and copper for PV systems are higher for the climate-change-mitigation option, only one year of iron production and two years of global copper, based on current utilization rates, are necessary to build a low-carbon energy system to supply global electricity requirements in 2050.

Asdrubali et al. (2015) suggest that LCA results of renewable energy technologies vary greatly and limit the utility of such results to inform policy makers. They review various case studies regarding hydraulic, geothermal, solar and wind power, and normalize the results to enable comparisons of the assessment results. Based on their assessment of acidification, eutrophication and global warming potentials, wind power technologies are shown to have the lowest overall environmental impacts while geothermal and PV technologies are shown to have higher impacts.

Connolly et al. (2016) perform an environmental assessment of a 100\% renewable energy system in Europe by 2050 and compare it with a business-as-usual scenario. In the renewable energy scenario, several technological changes that involve the use of biomass, solar and wind energy resources are suggested. They measure total annual $\mathrm{CO}_{2}$ emissions to analyse the impact of the two scenarios on the environment and show reductions in $\mathrm{CO}_{2}$ emissions for each of the technological changes that must be made to achieve a $100 \%$ renewable energy system.

Stougie et al. (2018) perform an economic, environmental and exergetic sustainability assessment of several power generation systems: coal-fired power plants (with and without carbon capture and storage), a solar PV park, an offshore wind farm and a biomass-fired power plant. Their study includes three environmental damage categories: human heath, ecosystems, and resources. The solar PV park and offshore wind farm are the top two systems with the highest environmental sustainability indicator scores, i.e., lowest environmental impacts.

Jacobson (2009) reviews and ranks two biofuel options and various electricity sources, including concentrated solar power (CSP), solar PV, geothermal, wind, hydroelectric, tidal, wave, nuclear, and coal with carbon capture and storage, according to their environmental impact potentials. In comparing options, their abilities to power advanced technology vehicles are considered, like flex-fuel vehicles that operate on biofuels, hydrogen fuel cell vehicles (HFCVs), and battery-electric vehicles (BEVs). They conclude that use of CSP, solar, wind, geothermal, tidal, wave, and hydraulic energy for providing electricity to HFCVs and BEVs achieves the lowest impact of the considered options.

Abbasi and Abbasi (2012) examine scenarios for producing electricity from various renewable energy technologies, in centralized large-scale systems or on a small-scale, and assess the direct and indirect impacts over the long term of widespread use of renewable energy technology (Table 1). Panwar et al. (2011) review various renewable energy technologies like solar water heaters, dryers and cookers, and biofuel and hydrogen technologies. For energy conservation, they suggest using in developing nations solar drying of agricultural products and wind energy, and using biodiesel from nonedible vegetables as suitable options for $\mathrm{CO}_{2}$ mitigation. 
Table 1. Potential negative environmental impacts of renewable energy options (adapted from Abbasi and Abbasi, 2012)

\begin{tabular}{|c|c|c|}
\hline $\begin{array}{l}\text { Renewable energy sources and related } \\
\text { technology }\end{array}$ & Environmental impacts & $\begin{array}{l}\text { Relative } \\
\text { magnitude }\end{array}$ \\
\hline Biomass production: centralized & $\begin{array}{l}\text { Land and water quality degradation, water consumption, stress on ecosystems } \\
\text { (common to large-scale plantations) }\end{array}$ & Major \\
\hline Biomass production: dispersed & Forest depletion, human encroachments & Medium \\
\hline Biomass combustion & Air pollution & Major \\
\hline \multirow[t]{5}{*}{ Direct solar: centralized } & Loss and degradation of large land tracts covered by reflectors & Major \\
\hline & Habitat loss from to land loss and degradation & Major \\
\hline & Indirect pollution from manufacturing storages and collectors & Major \\
\hline & Hazardous pollutant generation from decommissioning & Major \\
\hline & Impact on micrometeorology & Major \\
\hline \multirow[t]{2}{*}{ Direct solar: dispersed } & Adverse albedo & Medium \\
\hline & Interference of tree canopies with buildings having solar collectors & Minor \\
\hline \multirow[t]{5}{*}{ Wind energy: centralized } & Noise due to generators & Minor \\
\hline & Aesthetic degradation & Minor \\
\hline & Interference with bird flights & Medium \\
\hline & Ecosystem stresses from reduced downstream wind speeds & Minor \\
\hline & Television interference & Medium \\
\hline \multirow{6}{*}{$\begin{array}{l}\text { Hydroelectric power: } \\
\text { centralized }\end{array}$} & Loss of habitat & Major \\
\hline & Loss of water quality & Major \\
\hline & Loss of forests & Major \\
\hline & Emission of greenhouse gases & Major \\
\hline & Impediment of river flow & Major \\
\hline & Aquatic life stress & Major \\
\hline Hydroelectric power: mini and micro hydro & Impact similar to large-scale systems & Major \\
\hline Oceans thermal energy conversion (OTEC) & $\begin{array}{l}\text { Impact on marine ecosystem (eutrophication, algal blooms, altered water } \\
\text { chemistry and thermal structure, and addition of xenobiotics in the form of } \\
\text { biocides) }\end{array}$ & Major \\
\hline \multirow[t]{6}{*}{ Geothermal } & Surface distributions & Medium \\
\hline & Land subsidence & Major \\
\hline & Noise & Minor \\
\hline & Thermal pollution & Major \\
\hline & Air pollution & Medium to major \\
\hline & Water pollution & Medium to major \\
\hline Urban waste incineration & Air pollution (especially dioxins, furans, toxic metals) & Major \\
\hline
\end{tabular}

Tsoutsos et al. (2005) suggest that wide-scale deployment of solar energy systems may have negative environmental implications. They assess the potential environmental impacts of solar energy systems such as visual disturbances and noise during construction and installation, energy consumption, GHG emissions, soil and water pollution, impacts on sensitive ecosystems and archaeological sites, labour accidents, and positive and negative socio-economic effects.

A sustainability index, based on how exergy efficiency relates to sustainable development, is proposed by Rosen et al. (2008), who demonstrate that exergy is a better measure than energy for identifying the environmental and economic benefits of energy technologies. Hepsali (2008) also presents exergy analyses and performance evaluations of a range of renewable energy resources and technologies using energy, exergy and entropy balances with exergy efficiency, exergetic improvement potential rate and other parameters (e.g., relative irreversibility, exergetic factor, fuel depletion ratio and productivity lack). The results show that ground heat pumps have higher exergy efficiencies than wind energy applications, geothermal power plants and solar energy applications.

Although the marine environment represents a significant potential resource for energy production, concerns exist regarding the potential environmental impacts on biodiversity of marine renewable energy systems. Inger et al. (2009) examine such potential environmental impacts as habitat loss, noise, electromagnetic fields, and collision risks, and suggest that, marine renewable energy installations, when managed and designed appropriately, potentially can benefit the marine environment and increase local biodiversity. Such installations can act as fish aggregation devices as well as artificial reefs, which have been utilized to restore marine-protected regions and damaged ecosystems previously, and have demonstrated a capacity for enhancing biodiversity and fisheries. Desholm and Kahlert (2005) examine the effects of offshore wind farm installations on wildlife, in terms of collisions with geese and ducks, by tracking bird diurnal migration patterns with radar and examining birds' abilities to detect large offshore wind farms and to avoid them. The fraction of flocks entering a wind farm significantly decreased between preconstruction and initial operation (i.e., less than $1 \%$ of geese and ducks migrated sufficiently close to the wind turbines to be at significant risk of collision, relative to the numbers before the turbines were in place). Modelling of avian collision risk remains inaccurate because of a lack of data on species-specific avoidance responses; data is needed on demographic sensitivity of species affected by offshore wind turbines, consequences of habitat modification and avoidance flights, and avoidance responses (Fox et al., 2006). 


\section{Energy Sustainability and Sustainable Development}

Energy sustainability is a key contributor to overall sustainability in light of its importance in living standards and economic development and its environmental impact, in addition to the pervasiveness of energy use. Factors like the benefits of increased energy conversion efficiency, the availability of renewable energy sources that can replace fossil fuels and social impacts need to be accounted for in making energy systems more sustainable. The impact of alternative energy sources on global sustainability, and the relation between them, have been reviewed at various times (Ayres et al., 2007; Campos-Guzmán et al., 2019; Evans et al., 2009; Chu and Majumdar, 2012; Rosen, 2009).

In moving towards energy sustainability, various factors need to be addressed, such as utilizing sustainable energy resources and sustainable energy carriers, reducing environmental impact, increasing efficiency and improving socioeconomic acceptability (Rosen, 2009). Evans et al. (2009) assess renewable technologies for electricity generation that are not combustion based with various sustainability indicators: availability of renewable sources, energy conversion efficiencies, price of generated electricity, GHG emissions during the full life cycle, water consumption, land requirements and social impacts. The electricity cost, the quantities of GHG emissions and electricity generation efficiency are found vary widely for each technology, mainly due to the geographical dependence and technical differences among renewable energy resources.

Chu and Majumdar (2012) discuss various research and development pathways and options that could contribute to a secure and sustainable energy future, focusing on the transportation and electricity generation sectors. The pathways include batterybased electrification, fuel-cell-based electrification, use of compressed natural gas, and production and use of alternative transportation fuels.

Ayres et al. (2007) explore two tied concepts related to energy's role in economic development, and the potential for increased energy efficiency for reduced GHG emissions and sustained growth. One concept is that a near-term practical strategy for supporting technology-driven economic growth while attaining GHG emissions reduction exists, and that this strategy requires improved regulation or deregulation of the electric power sector rather than new technologies. The other concept is that, although reduced GHG emissions are needed for long-term global sustainability, the normal policy recommendation of increasing energy costs through a carbon tax may be somewhat ineffective under present market structures and impede economic growth unnecessarily.

\section{TYPES OF RENEWABLE ENERGY}

Increasing global energy demand and environmental concerns, in conjunction with renewable energy technology advances, are creating various new options for renewable energy resource utilization.

\section{Solar Energy}

Solar energy has received great attention, relative to other renewable energy resources, from the renewable energy community. Solar thermal energy and PV technologies have helped make solar energy one of the most exploited renewable energy sources. However, their energy efficiencies and intermittent nature have limited their share of global energy supply. Integration of these two technologies, as photovoltaic-thermal (PV/T) collectors, can increase efficiency and expand solar energy utilization, and has been the topic of recent research.

A solar thermal collector absorbs incident solar radiation as heat and transfers it to a circulating fluid. The circulating fluid carries the heat to systems where it is directly used for heating applications or, at high temperatures, to a power generation plant where the heat can be used to generate electricity. Some solar collectors are designed to concentrate the solar radiation to a line or a point and thus receive a much higher rate of solar radiation. A number of concentrated solar collector types exist based on how they concentrate and the technology that receives the solar rays. Concentrated solar thermal applications are attracting growing attention from solar energy researchers and practitioners. The applications sometimes exhibit good performance in terms of energy conversion efficiency and storage density. Tian and Zhao (2013) review thermal energy storage systems, solar collectors including concentrating (for high temperature applications) and non-concentrating (for low temperature applications), and the latest developments in solar thermal applications. Various solar collector types, are discussed in terms of heat loss reduction and recuperation, optical optimisation, and improved solar tracking. Of non-concentrating collectors, PV/T solar collectors exhibit the best overall performance. Reddy et al. (2016) comprehensively review solar thermal power plants, focusing on state-of-the-art technologies, and report results of technical and economic feasibility studies in India. They suggest that the solar power cost may become competitive in the near future if energy losses at several locations of the power system, i.e., generation, distribution and transmission losses, and environmental degradation are taken into account.

Among solar energy technologies, crystalline silicon PV is proving to be one of the most advantageous ways to generate electricity on a large scale. PV alternatives include amorphous silicon (a-Si), cadmium telluride (CdTe), and copper gallium indium selenide (CIGS) cells (Armaroli and Balzani, 2016). The limited availability of the mineral and other natural resources required to manufacture PV panels and storage devices on a large scale is a factor reducing the sustainability of some PV technologies such as CdTe and CIGS (Armaroli and Balzani, 2016). Mirrors and/or lenses are used in concentrated PV technologies to focus sunlight to a PV cell surface to reduce material requirements. Parida et al. (2011) review PV technology and its electricity generation ability, relevant light absorbing materials and environmental aspects, and describe numerous applications of PV. Present models for performance and reliability, control and sizing methods, and grid connection and distribution are described.

Kumar and Rosen (2011) review PV/T solar collectors for air heating and investigate the practicality of using PV/T collectors in applications such as space heating and drying as opposed to using separate PV and thermal systems. It is found that, although 
PV/T collectors are promising, efficiency and cost are still issues that need to be resolved to foster their widespread use. Several water desalination methods using solar and wind energy resources are reviewed by Darwish et al. (2012). Hybrids energy systems incorporating fossil fuel and solar systems have the potential to reduce fossil fuel use. Such technologies include CST for feedwater preheating and back-up boilers in a solar Rankine cycle (Nathan et al., 2018). The use of biomass and/or renewable fuels instead of fossil fuels permits carbon-negative energy at a relatively low cost.

Other solar energy conversion systems also exist, but are in the concept stage. They include other PV technologies (e.g., organic PV and dye-sensitized solar cells), thermoelectrics that directly convert solar thermal energy to electricity (Huen and Daoud, 2017) and photosynthetic systems that directly produce electricity or store solar energy in molecular hydrogen, by water splitting systems, or as a hydrocarbon fuel using sunlight, water and $\mathrm{CO}_{2}$ (Armaroli and Balzani, 2016; Lewis, 2016; Wang et al., 2018c). The first photosynthetic system has issues of solar radiation intermittency, but the second one has the advantage of many other fuels in its capacity to be efficiently stored and transported for later use (Romero et al., 2017).

\section{Wind Energy}

An indirect type of solar energy, wind is caused by the differential solar heating of the surface of the earth. In such areas as northern Europe and the southern US, wind energy resources can satisfy the entire electrical demand in theory.

Kaygusuz (2009) reviews recent progress on wind energy and discusses the potential of utilizing this technology worldwide. Topics often discussed include site selection, performance assessment, wind turbine component problems, wind resource aerodynamic models (including wake effects), wind energy grid connectivity issues, control systems, economics, and design loads (Herbert et al., 2007). Chingulpitak and Wongwises (2014) critically review wind energy in Thailand and future plans for its utilization in electricity generation instead of fossil fuels.

When space for onshore wind turbines is scarce, offshore wind energy is becoming more popular in many jurisdictions (Østergaard et al., 2020). Breton and Moe (2009) describe the status of wind energy technology, the potential for offshore wind energy, and plans for offshore wind parks in North America and Europe. They also describe existing and new options for offshore wind energy.

Accurate forecasting of wind power density is essential for planning and operating wind farms. Koračin (2012) reviews the primary challenges in forecasting and assessing wind and wind energy generation. These include advantages and limitations of wind forecasting as well as wind power density assessments, taking into account the trend for improved storage capacities of wind-generated power and increasing penetration of wind-generated power into the utility grid. They also review various prediction tools including the effect on wind power density of wind variability as well as atmospheric turbulence, stability and low-level jets.

The utilization of hybrid wind energy systems such as wind/solar systems are increasing. Issues related to system feasibility, optimized sizing using evolutionary optimisation techniques, modelling, control, and cost estimation (e.g., game theory) are current topics in the field of wind/solar hybrid systems (Khare et al., 2016).

Stehly et al. (2017) show a decreasing trend in 2017 from an earlier study determining the wind energy cost in 2010 (Tegen et al., 2010). They find the levelized cost in the United States of electricity for land-based, fixed-bottom and floating offshore wind plants as $\$ 47 / \mathrm{MWh}, \$ 124 / \mathrm{MWh}$ and $\$ 146 / \mathrm{MWh}$. They show that the levelized costs vary widely based on changes in a number of factors, such as net capacity factor, project design life and capital expenditures.

\section{Geothermal Energy}

Like solar and wind energy, geothermal energy is abundant and renewable. It is available as hot water or steam, generally in two reservoir types (i.e., low permeability or dry basement rock and permeable rock) at volcanic regions or boundaries of plates of the earth crust. Unlike solar and wind energy, geothermal energy is available all year and all day, so it can balance or supplement intermittent energy sources. However, only a small portion of available geothermal energy is currently used commercially to generate electricity or provide useful heating, in part due to the current state of the technology that can only extract energy at boundaries of plates of the earth crust where natural reservoirs exist (Clauser and Ewert, 2018).

Where natural reservoirs exist, direct heating with geothermal energy is usually ecconomically competitive with conventional energy resources. Future scenarios for development show a moderate rise in traditional direct geothermal applications. Carlino et al. (2012) describe past research on using the Campanian volcanos in Italy as sources of geothermal energy and review data and technical reports to correlate the temperatures measured in deeper wells with potential geothermal heat sources in the shallow (depths of about 8-10 km) crust. They assess geothermal potential for some areas, such as Ischia Island and Campi Flegrei, which exhibit favourable physical conditions for reliable and cost-effective exploitation of geothermal energy for thermal and electric purposes. Advances in technologies for engineering man-made reservoirs, such as enhanced geothermal systems, in low permeability reservoirs are needed to enhance this growth. Artificial fractures can be enhanced in such reservoirs through injecting high pressure fluid in the area of the wellbore to create shear cracks and absorb heat (Gallup, 2009). Many similar advances and existing sites are reviewed in the literature (Gallup, 2009; Lu, 2018). Appropriate geothermal fracking technology that can operate at large depths is shown to have the potential for delivering much energy in locations where natural geothermal reservoirs do not exist (Jain et al., 2015). Clauser and Ewert (2018) suggest that the investments to advance such technologies comes at high risk, but are needed to render geothermal technology comparable to other technologies such as solar, wind and nuclear. Funding of geothermal energy research at a much larger scale than previously done is needed to achieve such a goal. Based on existing assets, data and technologies, Wang et al. (2018a) suggest the utilization of oil wells over traditional geothermal wells has significant advantages, in terms of reduced operational risks and capital expenditures. They introduce multidisciplinary technologies, such 
Temperature $\left({ }^{\circ} \mathrm{C}\right)$

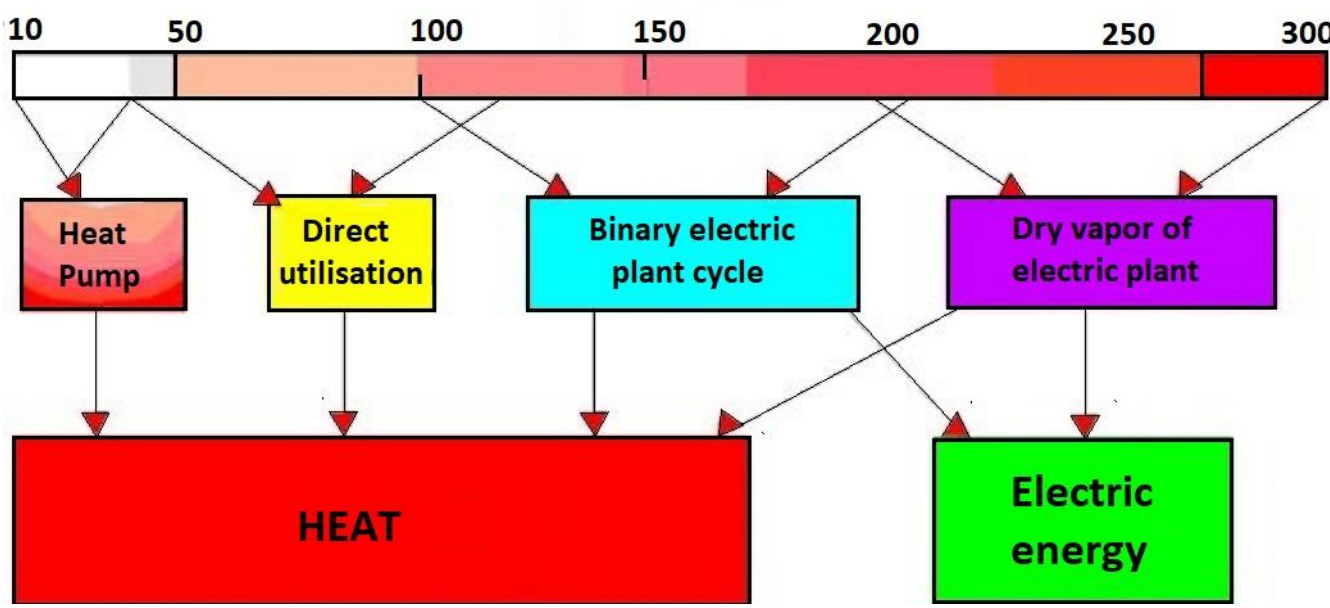

Figure 2. Dependence on temperature of applications of hydrogeothermal resources (reproduced from Milenić et al., 2010)

as thermoelectric and nanotechnology, as options to enhance the potential and promote geothermal energy development from oilfields.

An exponential-like rise is expected in the heat pump sector, as ground source heat pumps (GSHPs) in most parts of the world can provide heating and/or cooling. Yang et al. (2010) and Omer (2008) describe ground source heat pump systems and their advances, while a more detailed review of developments in vertical-borehole ground coupled heat pump systems for applications in air-conditioning (heating and cooling) is provided by Yang et al. (2010). The coefficient of performance in GSHP systems directly depends on physical and operating characteristics (e.g., heat exchanger inlet fluid temperature) of the ground heat exchanger. The use of GSHPs in conjunction with solar thermal systems could positively impact the heat exchanger and the GSHP performance (Noorollahi et al., 2018). Lucia et al. (2017) review analytical approaches using the second law of thermodynamics for GSHPs and suggest the approaches for optimizing GSHP designs. Various applications of geothermal energy such as geothermal heat pumps, space heating, agribusiness applications, industrial applications, agricultural drying, snow melting and space cooling are reviewed by Lund (2010), along with descriptions of the requirements of each application. For geothermal energy to meet a larger portion of global energy requirements, research is needed to improve the technology. Milenić et al. (2010) investigate the reconstruction of the energy systems of existing old buildings in Serbia, which were not originally designed for low energy consumption, with direct and indirect use of groundwater energy. They report the criteria for direct and indirect use of hydrogeothermal energy use as groundwater quality, quantity and temperature (Figure 2).

\section{Bioenergy and Waste-derived Energy}

Solar, wind, wave and tidal energy are taken as renewable and over the relatively long term sustainable. Depending on how they are managed, biomass fuels and wastes can be viewed as sustainable energy resources (Figure 3 ). Biomass, defined as biological matter from once living organisms, includes energy crops, wood wastes, agricultural crops, aquatic plants, and municipal and animal wastes. An alternative energy source, biomass is used either directly by combustion to produce heat or indirectly after conversion to biofuels or biogas. Biogas can be produced from organic digestion by mixed populations of microorganisms under anaerobic conditions, providing a beneficial pathway for utilizing some biomass categories to satisfy energy demands. Compared to other renewable energy forms, biogas is not restricted geographically. Wastes also are convertible to useful energy forms such as biogas, bioalcohol and biohydrogen via waste-to-energy technology. Processes for converting biomass to an upgraded fuel are categorized in Table 2. Such processes could result in unwanted by-products, including toxic and hazardous pollutants. Arevalo-Gallegos et al. (2017) emphasize the importance of considering green principles while developing future biorefinery platforms for producing sustainable, eco-friendly and recyclable products. Various processes are often reviewed, compared and/or examined for various biomass types to find the optimum option for each biomass type (Gollakota et al., 2018). Sometimes, a given process for a biomass type is studied to compare and understand various technologies, feedstocks, reactors and end-product properties (Dhyani and Bhaskar, 2018).

At present, biofuel production accounts for only about $2 \%$ of global annual gasoline consumption. The contribution to energy supply of biofuels is likely to increase due to the associated benefits of its use, including reduced GHG emissions, new income sources for farmers and enhanced energy security.

Various differing conclusions have been reached about the future contribution of biomass to the global supply of energy. This is mainly due to uncertainties in yield levels for energy crop production, land availability and future expectations about availability of forest wood and forestry and agriculture residues. In addition, energy use in growing biomass, i.e., planting, watering, use of chemicals and pesticides to achieve higher yields, harvesting, and drying may prove to be high or provided from fossil fuel sources (Infield and Freris, 2020). Beran and Dyckhoff (2019) review biomass contribution to the current global energy supply and suggest that replacing fossil fuel resources with biomass to mitigate current climate and energy concerns might hinder future sustainability efforts. 


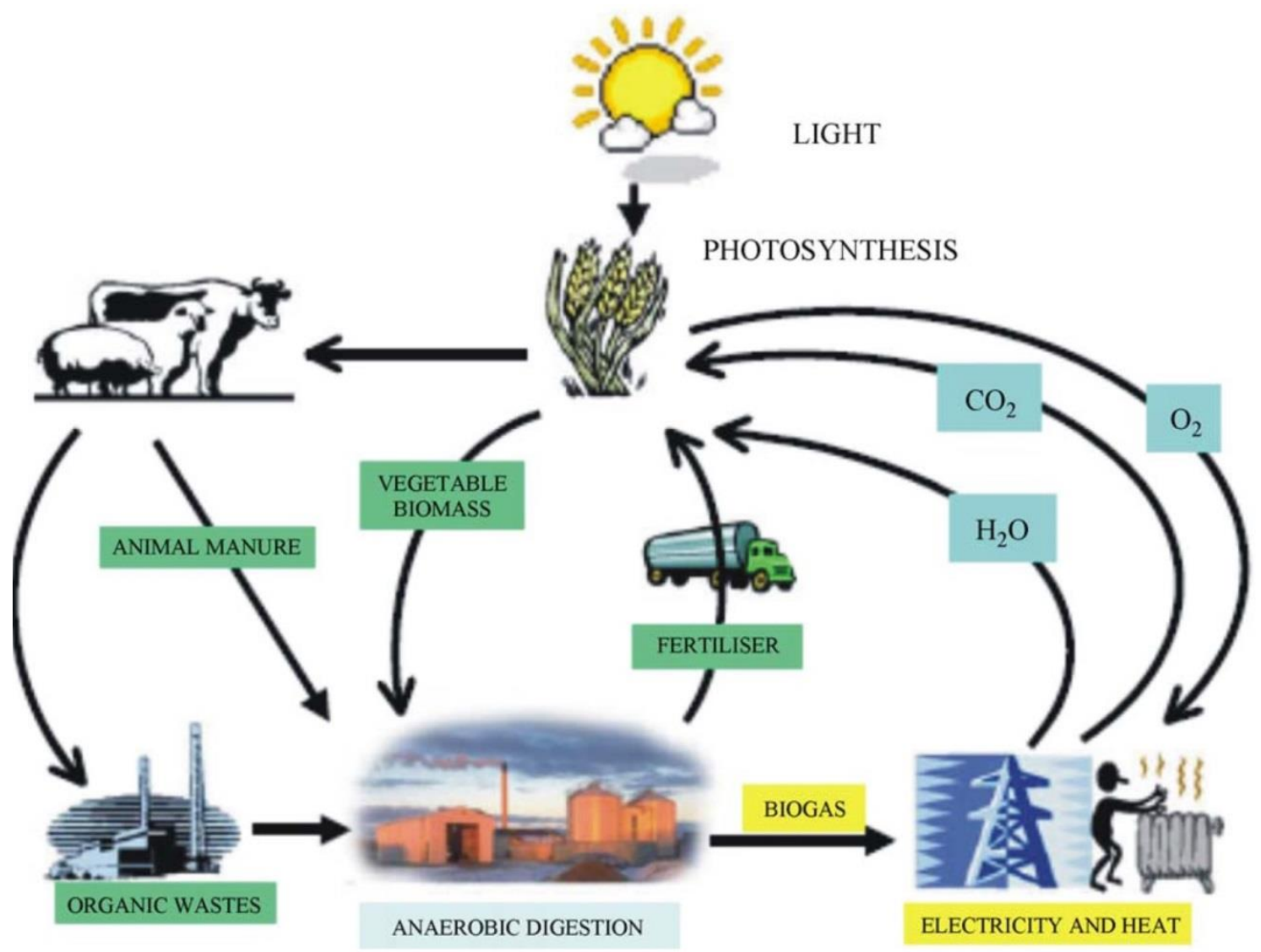

Figure 3. Sustainable cycle of anaerobic co-digestion of organic wastes and animal manure (reproduced from Al Seadi, 2002)

Table 2. Categories and processes for converting biomass to energy (adapted from Abbasi and Abbasi, 2012)

\begin{tabular}{ll}
\hline Conversion category & Conversion process \\
\hline Biochemical & Fermentation \\
& Aerobic fermentation \\
& Anaerobic digestion \\
\hline Chemical & Transesterification \\
\hline Thermal & Direct combustion \\
& Pyrolysis and torrefaction \\
& Gasification \\
& Liquefaction (hydrous pyrolysis) \\
\hline Thermochemical & Conversion to methanol \\
\hline Other (novel ideas, unproven concepts, etc.) & Biophotolysis \\
& Hydrocarbon extraction \\
& Hydrogasification \\
& Electrochemical oxidation (e.g., in fuel cells) \\
\hline
\end{tabular}

China has one of the largest straw resource supply in the world. Zeng et al. (2007) review present technologies for utilizing straw as biomass, including biogas production, straw gasification and straw briquette manufacture, and discuss other technologies, such as straw carbonization, liquefaction and bio-coal (a mix of coal and straw). Research is proposed on using in China straw as part of the biomass energy mix, based on its current technology status. One challenge to the growth of biomass as a fuel is scarcity of water and land resources, which already constrain agricultural food production in many countries including India and China. de Fraiture et al. (2008) explore the water and land impacts of increased global biofuel production, especially for India and China, concluding that high water resource demands in India and China make it unlikely that biofuel options based on traditional field crops will be pursued. Raising biofuel production on arable land could affect global food supply significantly. But, biodiesel production from algae is generally considered as one of the most advantageous methods for biofuels generation. An advantage of second generation microalgal systems is their capability to produce a broad range of feedstocks for bioethanol, biodiesel, biohydrogen and biomethane production. Schenk et al. (2008) describe second generation biodiesel production from microalgae. A primary limitation to microalgae processing for biofuel production at an industrial scale is the dewatering process. The dilute character of harvested microalgal cultures leads to large dewatering operating costs, making algae-based fuels economically less attractive. There currently is no better dewatering method for microalgae. Uduman et al. (2010) compare current dewatering technologies for microalgal cultures. One option for exploiting microalgae's energy content is direct anaerobic digestion of raw algae, for methane production and nutrient recycling. Collet et al. (2011) compared first generation biodiesels with algal biodiesel through a life-cycle assessment (LCA) of biogas production from a microalgae (Chlorella vulgaris). 
Mathews (2008) uses energy and exergy analyses to examine a proposed biomass integrated fired combined cycle using paper, municipal waste, paddy husk and wood in biomass gasification and compare the system energy efficiency when the cycle uses natural gas and the four kinds of biomass or just natural gas.

While the use of biomass or biofuels addresses many energy sustainability issues, debates are ongoing over their contributions to global warming mitigation. Sequestration of atmospheric carbon can potentially address the earth's greenhouse gas problems. Returning biochar to the soil sequesters carbon and improves the soil vitality and fertility. Soltani et al. (2013) review potential benefits of using carbon-negative biofuels. Kothari et al. (2010) investigate potential renewable energy technologies and their contributions to sustainable development, emphasising waste-to-energy routes, energy use and environmental impact patterns, and environmental protection options.

The potential for the treatment of fruit and vegetable waste, manure and solid slaughterhouse waste in co-digestion is assessed experimentally based on semi-continuous mesophilic anaerobic digestion by Alvarez and Liden (2008). They also investigate co-digestion in a mixture experiment using ten feed compositions, including materials such as fruit and vegetable wastes, and show that digestion of mixed substrates usually superior to that of pure substrates.

Biogas production processes are reviewed by Balat and Balat (2009), as is biogas characterization as an alternative energy resource. Abbasi and Abbasi (2010) review numerous biomass sources and possible pathways for its use for generating energy and examine the environmental impacts of various biomass energy generation-utilization options. Holm-Nielsen et al. (2009) review anaerobic digestion of animal manure and various biogas production plant concepts.

Pant et al. (2010) investigate possibilities for generating electric current from renewable biomass and a range of dissolved or soluble complex organic wastes. Substrates examined for microbial fuel cells, their limitations and performances, and potential new substrates are reviewed. The substrates include lignocellulosic biomass and real and artificial wastewaters.

\section{Tidal, Wave and Hydraulic Energy and Ocean Thermal Energy}

Interest is growing globally in the utilisation of ocean energy, partly due to its widespread availability. The energy potentials in oceans can generally be classified in five groups: surface wave energy, tidal energy, ocean current (circulation) energy, ocean thermal energy, and salinity gradient energy. The contribution of ocean energy to the global energy supply remains small, in part due to technological challenges. As of 2015, among the various ways ocean energy can be harvested, tidal power contributes the most power in terms of installed capacity to the global power supply, followed by ocean currents, while salinity gradient energy contributes the least (Hussain et al., 2017). Research in this area is often focused on analysis of the technical and financial feasibility of selected areas for harvesting ocean energy, performance analysis of installed technologies and environmental analysis of proposed technologies. Zabihian and Fung (2011), and Pelc and Fujita (2002) review the status in harnessing the various forms of marine energy. Zabihian and Fung (2011) describe the features of seas and lakes in Iran from an energy viewpoint and examine possibilities for using these energy resources.

Wave energy is in many countries increasingly considered as a potential energy source as it has a high spatial concentration of energy in comparison to other renewable energy resources. Wave energy is derived from the wind as it blows on the water surface in the ocean and causes wave formation. As a result, wave energy potential depends on wind strength, which is highest at the eastern boundaries of oceans, between $40^{\circ}$ and $60^{\circ}$ north and south latitudes (Hussain et al., 2017). This gives the UK the highest wave energy potential and the location with the most wave energy technology development (Bahaj, 2011). However, since wave energy is driven by wind, it is inherently unpredictable. de O. Falcão (2010) reviews a wide variety of factors related to wave energy, including the wave energy resource characterization, concepts and designs, construction and deployment, model testing, and the development of specific equipment and mooring systems. In Figure 4, they classify various wave energy technologies based on the working principle of each technology.

The potential of tidal energy is in the rise and fall of ocean levels due to gravitational and rotational forces between the earth, moon and sun. As a result, this source of energy is regular and predictable. The main energy conversion devices in a tidal power plant are hydrokinetic turbines and the working principal has many similarities to that of a hydro power plant. Bahaj (2011) reviews the current status of tidal streams and waves, and addresses issues related to these technologies. The paper also discusses financial mechanisms available in the UK to support this area of renewable energy, highlighting the economic approaches needed in technology development.

Ocean current energy is the result of the latitudinal disturbances of both thermohaline ocean circulation and winds. The behaviour of this source of energy is generally regular and predictable. Many such currents are found throughout the oceans. However, only those that are consistent and close to shore can be used for power generation (Unique challenges in harnessing open ocean marine hydrokinetic energy, 2017). The need for an electrical transmission infrastructure is one of the factors limiting their development. There are many similarities between the energy extraction techniques for tidal energy and ocean current energy. However, due to the variability of current flow speeds, more detailed physical oceanographic data sets are needed to develop energy extraction technologies (Hanson et al., 2011).

Ocean thermal energy originates from the sun. Solar radiation on the surface of the ocean causes a temperature gradient between water at the ocean surface and in deeper levels (800-1000 m) (International Renewable Energy Agency, 2014). Where the temperature gradient reaches approximately $20^{\circ} \mathrm{C}$, an open- or closed-cycle (or a hybrid) system of turbines and heat exchangers operates between the two high- and low-temperature mediums to generate electricity. Wang et al. (2011) review several facets of research on ocean thermal energy conversion, including energy utilisation, platform design and mooring systems, heat exchanger systems and environmental impact, and discuss developments in the construction of large-scale ocean thermal energy conversion facilities. Various other studies focus on the optimization of the system parameters such as energy efficiency, exergy efficiency and 


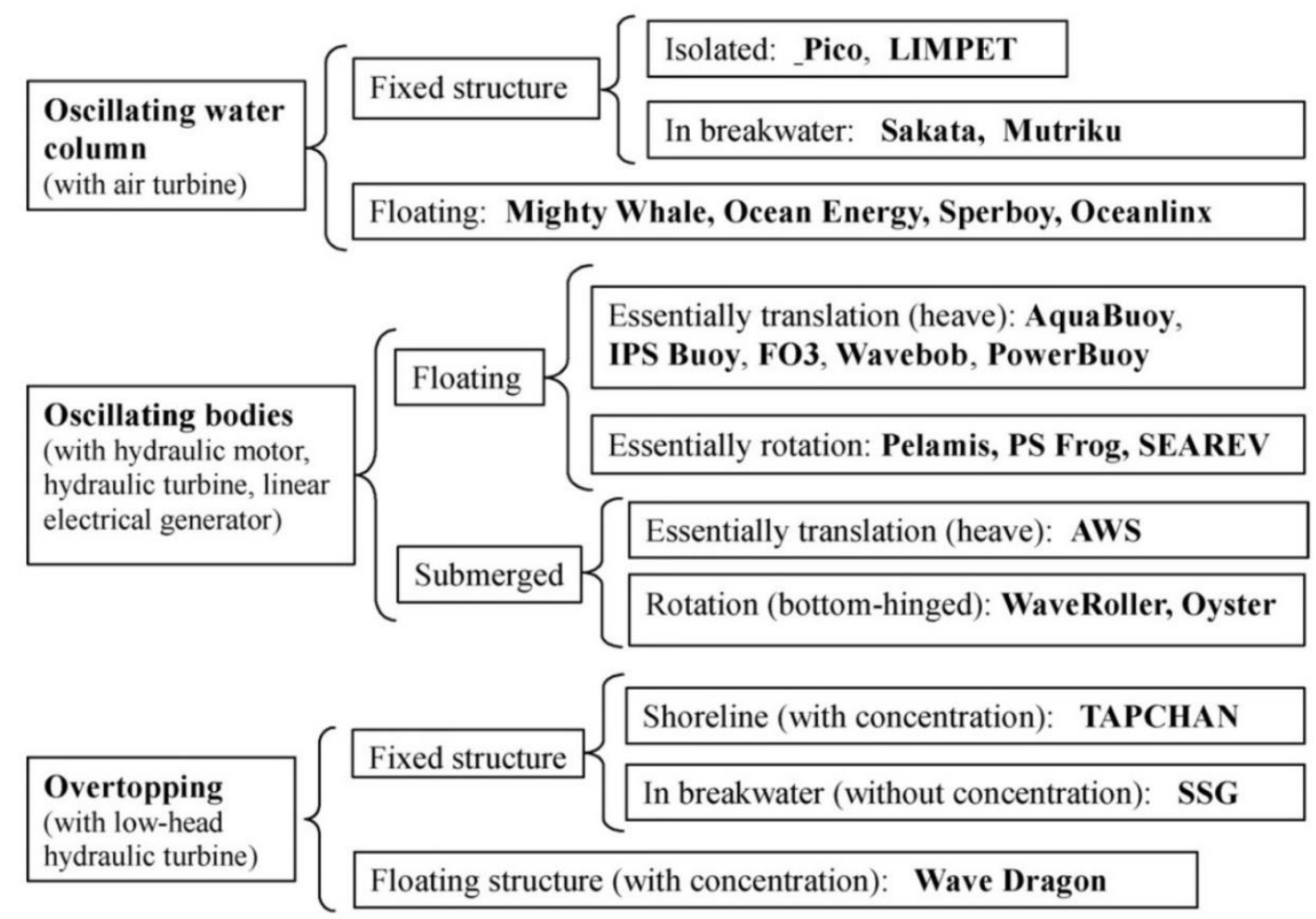

Figure 4. Various wave energy technologies (reproduced from de O. Falcão, 2010)

cost to achieve the highest net power output and thermal efficiency for the system (de O. Falcão, 2010; Unique challenges in harnessing open ocean marine hydrokinetic energy, 2017).

A hydrogen production method using solar proton exchange membrane electrolyser coupled with OTEC is proposed by Ahmadi et al. (2013). The OTEC turbine generates electricity for use in a PEM electrolyzer that produces hydrogen. The system exergy efficiency, the hydrogen production, and the component and the overall system exergy destructions are determined.

The source for salinity gradient energy lies in the chemical potential that exists between liquids of different salt concentration, i.e. osmotic power. Such potential exists in great levels between river and sea waters. Higher salt concentration differences, such as those achieved in natural hypersaline resources (like salt domes hypersaline and lakes) can provide higher power generation potential (Yip et al., 2016). Methods used for harvesting this energy are reverse electrodialysis, pressure retarded osmosis and capacitive mixing. The cost of the membrane and electrode, and fouling are currently some of the limitations to the development of this technology (Yip et al., 2016). A global assessment of extractable saline gradient energy resources shows almost half of river mouths are suitably located; the extractable potential is roughly $3 \%$ of the global electricity use (Alvarez-Silva et al., 2016).

Yang et al. (2017) propose a hybrid system for salinity gradient energy harvesting using solar energy. They use rapid water evaporation at a light absorber surface to create high-concentration salt water on the surface and, thus, a salinity potential between the water surface and the brine underlying the evaporation surface.

\section{ENERGY TECHNOLOGIES THAT FACILITATE RENEWABLE ENERGY USE}

Renewable energy sources often are used with technologies that can facilitate their use despite their limitations such as intermittency. Renewable energy facilitating technologies include multigeneration, energy system integration, district energy, energy storage, and hydrogen energy systems.

\section{Multigeneration and Integrated Energy Systems}

Increasing the portion in the primary energy mix of renewables can sometimes be advantageously accomplished through integrating renewable energy resources (wind, solar, biomass, etc.) with existing fossil fuel technologies or the electrical grid, and by the development of multigeneration systems that can meet electrical as well as thermal demands. Figure $\mathbf{5}$ shows an example of renewable energy integration with an existing system.

One challenge in increasing the share of renewable energy is its non-availability during parts of the year. Hybrid energy systems, integrating various energy sources in one system, can address this challenge by efficient use of sustainable and renewable energy resources and are, therefore, becoming popular in many countries. Much research has been reported in the past few years on the design, modelling (Bajpai and Dash, 2012; Deshmukh and Deshmukh, 2008; Paska et al., 2009), optimization (Bajpai and Dash, 2012), control and operation of hybrid renewable energy systems (Liserre et al., 2010). They include backup energy systems (e.g., fuel cells, batteries, ultra-capacitors, diesel generators) (Bajpai and Dash, 2012), power conditioning units 


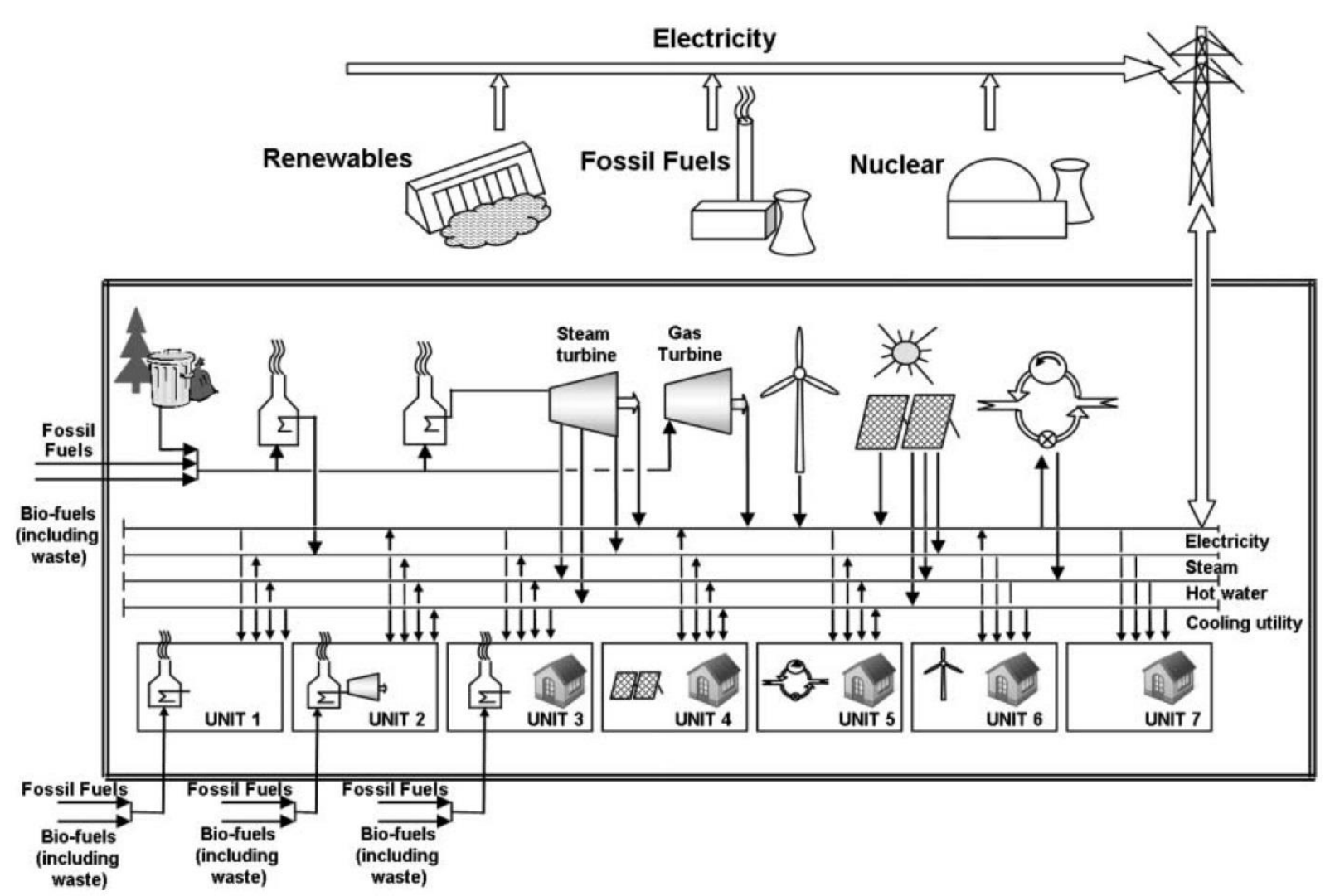

Figure 5. A total site integrating renewables (reproduced from Perry et al., 2008)

(maximum power point tracker converters, battery chargers, buck/boost converters) (Bajpai and Dash, 2012; Carrasco et al., 2006; Liserre et al., 2010), and methods and/or issues for the management of energy flow (Bajpai and Dash, 2012; Deshmukh et al., 2008). Hybrid combinations include solar-wind power plants (Paska et al., 2009), solar power plants with fuel cells (Paska et al., 2009) and wind power plants with battery energy storage (Paska et al., 2009) as well as combinations of fossil fuel and renewable energy power plants. Pepermans et al. (2005) review existing small-scale generation technologies, including renewable energy technologies, and their major benefits and issues. Hybrid ground source heat pump systems have also been used frequently in recent years, even though the integration and synthesis is demanding (Qi et al., 2014). Supplemental heat sources can be waste heat or solar thermal collectors.

Similar to fossil fuel co- and tri-generation plants, renewable energy sources can be utilized to provide electricity as well as heating and/or cooling (Azhar et al., 2017; Cuomo et al., 2018; Varbanov and Klemeš, 2010), whether they are integrated with a fossil fuel plant or used as the single source of energy in a multigeneration plant. For example, biogas can be used to run micro gas turbines to generate electricity and further provide cooling and heating using absorption chilling and an organic Rankine cycle that recovers heat (Cuomo et al., 2018). As another example, solar and geothermal energy sources can be utilized to provide electricity in a hybrid plant while the heat remaining in their low-pressure turbine is used in a desalination plant and a vapor absorption cycle to provide cooling. To further improve the overall system efficiency, the sea water for the desalination plant is used in an ocean thermal energy conversion plant to generate power that can offset part of the pump work that is required to extract the water for the desalination plant (Azhar et al., 2017). Thermal energy demands vary with the many types of end users (e.g., industrial, residential and agricultural) and their time schedules. For example, industrial sites mostly require heating (from $100^{\circ} \mathrm{C}$ to $400^{\circ} \mathrm{C}$ ), cooling (from $20^{\circ} \mathrm{C}$ to $50^{\circ} \mathrm{C}$ ), chilling (from $0^{\circ} \mathrm{C}$ to $10^{\circ} \mathrm{C}$ ) and refrigeration (below $-100^{\circ} \mathrm{C}$ ) (Varbanov and $\mathrm{Klemeš}$, 2010).

It cannot be concluded from analysis of a single type of demand or a single source of energy what strategy is superior to others with regards to enhancing renewable energy economics and performance. To balance the energy conversion processes in multigeneration systems with consumption of energy, Jørgensen et al. (2016) suggest a flexible multigeneration system that consists of flexibly operated and integrated plants that provide numerous ties between the energy system layers. The development of such a system requires systematic optimization approaches. The authors propose a methodology based on several important considerations including multi-objective optimization considering environmental and economic performance; location, selection, and sizing of processes, and flexible operation optimization regarding short-term market fluctuations. For example, a case study of a combined heat and power generation facility with waste incineration boilers as well as a gas turbine, both connected to a district heating system, has been studied (Jørgensen et al., 2017). The system is close to a heat and electricity user (a butchery). A flexible multigeneration system is proposed using a biorefinery having a solid oxide electrolysis cell (SOEC), a biomass gasifier, and a methanol production unit. Retrofit options included installation of the biorefinery either next to the combined heat and power (CHP) unit or the butchery. An investment in a district heating connection to the butchery was also 
considered in order to partially cover the butchery thermal demands. The optimization methodology of Jørgensen et al. (2016) shows that designs with the biorefinery situated near local industry outperforms in terms of economic and environmental objectives.

\section{District Energy}

In district energy systems, thermal energy is obtained directly or indirectly from an energy source, including renewable ones, in a central plant and either transported to the energy users via water or steam pipes for commercial and residential space and water heating or sent to a vapor absorption chiller to cool a working fluid, often water, that is then carried out to users for cooling and dehumidification purposes. For example, residential sites (e.g., dwellings complexes) and service buildings (universities, schools, hotels, banks, hospitals, governmental buildings, entertainment facilities) have various thermal energy demands such as space heating, cooking (e.g., using steam in hotels), steam sterilizing (e.g., in hospitals), and hot water (from $90^{\circ} \mathrm{C}$ to $150^{\circ} \mathrm{C}$ ) as well as electricity for heat pumps, air conditioning, and direct electricity consumption (e.g., for cooking, lighting, refrigeration). Such requirements can be met by connecting users via a district energy network to a thermal energy source that is dedicated to provision of thermal energy for the district energy system (e.g., solar thermal plants) or to a waste heat energy source (e.g., industrial waste heat (Popovski et al., 2018)) or to heat from multigeneration plants ( Varbanov and Klemeš, 2010). Common thermal energy sources are biomass (Kabalina et al., 2017), solar (thermal and PV) (Franchini et al., 2018), geothermal and surface water energy (Inayat and Raza, 2019; Østergaard et al., 2020). Inayat and Raza (2019) provide a detailed review of these energy sources for use in district cooling systems. Various studies focus on modelling and simulation of district energy systems (Andersen and Østergaard, 2019; Franchini et al., 2018; Olsthoorn et al., 2016), classifications and applications of district heating and cooling (Inayat and Raza, 2019; Olsthoorn et al., 2016; Rezaie and Rosen, 2012), integration of district energy with CHP (Rezaie and Rosen, 2012; Rosen and Koohi-Fayegh, 2016b) and future improvements via thermal network expansions (Rezaie and Rosen, 2012). Lund et al. (2010) compare fuel demand, $\mathrm{CO}_{2}$ emissions and costs of using various heating options in Denmark, including district heating, heat pumps and micro combined heat and power cycles. They conclude that substantial reductions in all three technologies can be attained by conversion to district heating, both in present systems and scenarios seeking by the year 2060100 per cent renewable energy supply.

Apart from reductions in $\mathrm{CO}_{2}$ emissions, fuel demand, and cost relative to other energy systems, district energy systems also provide an opportunity to utilise heat sources that would not be utilized on a small scale. For example, the use of heat from waste incineration, industrial processes, surface waters and geothermal resources may only be feasible when integrated with a district heating system.

While the general concept of district energy lies in the central generation of heated or cooled transport fluids that are distributed to users, the way the heated and cooled fluid is generated, its source, the temperature of the transport fluid and how efficiently users consume this energy define various generations of district heating systems. The latest generation (i.e., fourth generation) involves efficient buildings and distribution networks, sustainable generation using waste heat and renewable energy sources, the ability to act as an integrated element of smart energy systems, as well as the ability for appropriate cost, planning and incentive structures (Lund et al., 2018). Compared to earlier developments in district energy systems, newer systems have building heating and cooling systems (e.g., underfloor heating systems) designed to work with lower-temperature heating (Schmidt et al., 2017) $\left(55^{\circ} \mathrm{C} / 25^{\circ} \mathrm{C}\right.$ supply/return temperatures compared to $80^{\circ} \mathrm{C} / 45^{\circ} \mathrm{C}$ (Lund et al., 2018)) and higher-temperature cooling fluids. As a result, newer systems have lower distribution losses and better utilization of low-temperature heat resources (e.g., surface water and waste heat) and higher efficiency generation (e.g., higher efficiency CHP). They also include integration of various renewable energy sources as well as energy storage components to mitigate the challenges of the intermittency of renewable energy resources. It is often suggested that development of fourth generation of technologies is needed for district energy systems to take an effective future role in sustainable energy systems.

One potential limitation to the use of industrial waste heat and district energy systems for heating and cooling to users is the high mutual dependence between various stakeholders (e.g., the industry and the users as well as the city and utility) as well as risk and uncertainty (whether real or perceived). Policy instruments such as municipal energy planning and zoning as well as national ones can help overcome such barriers and ensure financial advantages for the individual stakeholders (Popovski et al., 2018).

District energy systems are shown to be economically feasible in various studies. Kabalina et al. (2017) demonstrate that a polygeneration district heating and cooling system incorporating biomass gasification has an investment payback period as low as 3 years and an efficiency of approximately $84 \%$. Franchini et al. (2018) demonstrate the economic advantages of a solar cooling system using two-stage absorption chillers and solar parabolic troughs in the climate of Riyadh, Saudi Arabia, i.e., high irradiation levels with low humidity levels. A case study comparing various energy provision options for heating and cooling of residential buildings in a city in Portugal (Popovski et al., 2018), shows the district energy system option to be the most competitive among all other options. The options considered include air-source heat pumps for heating, vapor compression chillers for cooling and solar PV panels for providing electricity to run the heating and cooling systems as well as using excess heat from a nearby refinery by a district energy system. Fourth generation district energy systems require changes to all three components of district energy systems (i.e., generation, distribution and buildings), but it is shown that existing as well as new buildings and distribution grids can be converted to the fourth generation concept at minor costs (Lund et al., 2018).

Environmental impacts of district energy systems that use renewable energy sources are often performed by assessing climate change potential of various renewable energy options compared to fossil fuel ones. However, a life cycle assessment comparing environmental impacts of conventional heating and cooling systems with district energy systems using natural gas, ground-source heat pumps and biomass in Italy (Bartolozzi et al., 2017) shows that renewable energy system options may have greater impacts 
than fossil fuel scenarios in some impact categories. For example, the biomass district energy system is shown to have higher terrestrial eutrophication impact and particulate matter emissions than other scenarios, including natural gas options.

\section{Energy Storage}

Renewable energy systems often benefit from or require coupling with energy storage, because of renewable energy intermittency. This approach has numerous advantages over current strategies of making utilities address transmission cost and supply uncertainties. It also increases utilization levels of renewable energy sources.

Studies are often divided to two categories: thermal energy storage (Alva et al., 2017; Koohi-Fayegh and Rosen, 2020; Tian and Zhao, 2013), including sensible and latent heat storages and thermochemical energy storage, and electrical energy storage (Carrasco et al., 2006; Koohi-Fayegh and Rosen, 2020), including flywheels, batteries, pumped energy storage, compressed air energy storage, hydrogen and chemical energy storage, and magnetic energy storage. Various energy storage technologies are usable with various intermittent renewable energy sources and discussions are often among the technical and/or economical suitability of one storage technology over others for a given application. Studies are also focused on finding the most technically and economically viable energy and storage configuration in stand-alone systems. Future renewable energy trends based on maturity and reliability are likely to impact the focus on which storage type is more suitable for a given energy type.

Research on thermal energy storage technologies often involves heat transfer enhancement technologies, material selection and design criteria (Alva et al., 2017; Liu et al., 2016; Tian and Zhao, 2013) with relatively fewer studies focused on optimization of modelling techniques used in design and integration of renewable energy systems with energy storage technologies (van der Heijde et al., 2019). Several studies focus on energy storage technologies suitable for solar energy storage, from both solar thermal and PV technologies (Alva et al., 2017). Sensible and latent thermal energy storage technologies are in use in several solar thermal power generation plants (e.g., sensible storage tanks employing the storage medium of molten salt) and are assessed in several studies (Xu et al., 2015). Thermochemical energy storage technologies offer a potentially promising option for concentrated solar thermal power generation systems in the future, but they are still at early stages of development (Bayon et al., 2018). The present research focus is mainly on the selection of a suitable chemical reactions, improvements in heat exchangers involved in the process, improvements in storage density, thermal conductivity, cyclability and the costs of composite materials (Liu et al., 2016; Pelay et al., 2017; Prieto et al., 2016).

Energy storage technology sometimes is categorised based on its use in large- or small-scale applications. Flywheels, pumped energy storage and compressed air energy storage are among the storage types often used in large scales. Battery systems are expected to significantly impact small-scale integrations in commercial and residential buildings of renewable energy resources (Hemmati, 2017; Nair and Garimella, 2010).

Energy storage systems are an essential part of autonomous power supply systems (i.e., island and urban ones), often designed to supply electricity to houses, warehouses, lighting installations and staircases for small estates using hybrid renewable energy configurations incorporating solar PV and wind (Fedak et al., 2017). Kaldellis and Zafirakis (2007) investigate the effects on cost of utilizing selected energy storages in various autonomous electrical grids, to allow higher penetration levels of renewable energy. They show that compressed air energy storage and pumped hydro exhibit attractive electricity production costs.

One energy storage method involves storing harvested solar energy in chemical bonds, by producing from water a reduced fuel like hydrogen, methanol, methane, or other hydrocarbon species as well as oxygen, so as to reduce land-area requirements (Lewis and Nocera, 2006). Toledo et al. (2010) review energy storage and recovery systems linked to PV systems and propose a distributed micro-generation system using energy storage while being connected to the electrical grid. These systems seek an improved load factor, and consider supply side management and, provide backup energy in the case of demand side management. Hosseini et al. (2014) use energy and exergy analyses to investigate the efficiency of a hybrid biomass/PV system with energy storage, while hybrid wind/compressed air energy storage systems are examined by Cavallo (2007). Zhao et al. (2015) and Díaz-González et al. (2012) review several energy storages for wind power generation, including pumped, compressed air, electrochemical, chemical, flywheels, and magnetic energy storage.

\section{Hydrogen Energy Systems and Technologies}

Hydrogen energy and related technologies such as fuel cells are regarded by many as important for addressing the challenges posed by anthropogenic climate change. In the near term, hydrogen can be used to produce ammonia for co-firing in coal power plants to reduce carbon dioxide emissions. Subsequently, hydrogen can be used in fuel cells to provide continuous power from a variety of renewable and fossil fuels with low (or zero) GHG and pollutant emissions, and can offset the intermittency of many renewable energy types. At present, hydrogen is one of few energy carriers that is transportable, emits no pollutants and GHGs at the point of use, and can be produced from various renewable and other sustainable energy resources with low emissions. However, while engineering aspects of hydrogen storage and use are relatively well understood, some hydrogen production methods still require research.

The status of hydrogen and fuel cell technologies and the key scientific and technical challenges they face are reviewed by a number of researchers (Brouwer, 2010; Edwards et al., 2008; Hosseini and Wahid, 2016; Rosen and Koohi-Faegh, 2016a), along with projections for hydrogen and fuel cell use in a sustainable energy future. The challenges include the cost of production, utilization, storage and transportation of hydrogen, and must be overcome before hydrogen technologies can contribute significantly to more efficient and cleaner energy processes.

Since hydrogen is not naturally available in its molecular form, it is produced by chemically converting compounds that contain hydrogen including fossil fuels such as natural gas (approximately $76 \%$ of current hydrogen production) and coal, as well as water. Natural gas reforming currently is the least expensive hydrogen production method (US Department of Energy, 
Alternative Fuels Data Centre, n.d.). Hydrogen production from fossil fuels, although economically advantageous today, is viewed by many as a short-term due to limited supplies of fossil fuels. In addition, hydrogen production from fuels such as natural gas, methanol and gasoline also generates $\mathrm{CO}_{2}$ as a by-product ( 2.5 tons of $\mathrm{CO}_{2}$ per ton of natural gas (Hosseini and Wahid, 2016)). Such production paths can include carbon capture systems to avoid the negative environmental impacts of $\mathrm{CO}_{2}$. Other methods of hydrogen production corresponding to lower $\mathrm{CO}_{2}$ emissions include the use of biomass, low-carbon and carbon-free fuels and electrolysis of water (Ursua et al., 2012) using electricity from renewable and/or nuclear energy sources. Hydrogen production methods in development include high-temperature and photoelectrochemical water splitting as well as photobiological water splitting. However, they contribute only a small fraction of hydrogen production. Such methods offer opportunities to harvest and store energy from renewable sources with variable energy outputs (e.g., wind and solar) that would otherwise not be possible without an energy storage option. The high cost of such production paths to hydrogen as well as the low return on investment of energy for hydrogen production are among the main barriers of their development. Possible configurations for integrating renewable energy with water electrolysis in grid-connected, autonomous systems are being carried out to overcome such barriers. The utilization of renewable resources such as wind, solar, biomass and geothermal, to produce electricity for hydrogen production is reviewed in a number of studies (Hallenbeck, 2011; Hosseini and Wahid , 2016; Kuang et al., 2016; Muradov and Veziroglu, 2008; Turner et al., 2008; Yilanci et al., 2009). Turner et al. (2008) investigate renewable energy integration with hydrogen production from biomass materials such as forest residue and municipal sewage in addition to energy crops, and review longterm hydrogen production options from water utilizing solar energy such as photoelectrochemical water splitting and photobiological processes. Yilanci et al. (2009) assess solar-hydrogen/fuel cell hybrid energy systems with energy and exergy analyses and outline the current status. Hallenbeck (2011) reviews biological hydrogen production from lignocellulosic materials, waste streams and water, using solar energy and discusses technical barriers to commercialization as well as biological hydrogen production perspectives for the future. Muradov and Veziroglu (2008) analyze options for producing carbon-free power, including decarbonization of fossil fuels and use of nuclear and renewable energy resources, with a focus on hydrogen's role of as an energy carrier that is carbon free.

Hydrogen is currently used in industrial applications such as ammonia, methanol and steel production and oil refining. It is presently responsible for part of global $\mathrm{CO}_{2}$ emissions equivalent to the $\mathrm{CO}_{2}$ emissions of Indonesia and the UK combined (Kuang et al., 2016). However, it has the potential to meet demands in heating, power generation and transportation. There are opportunities for direct use of hydrogen for electricity generation with fuel cells and indirect uses in producing low-carbon synthetic fuels or in such carbon-free fuels as ammonia, for co-firing with fossil fuels in power plants to lower their $\mathrm{CO}_{2}$ emissions. Similar to the design of other hybrid energy systems, optimisation approaches are needed to design hydrogen fuel cell systems with optimal performance objectives not only in technical aspects but considering cost, environmental and socio-political factors (Eriksson and Gray, 2017).

Hydrogen can be stored and used subsequently during periods of energy demand. It is typically stored in tanks and to a smaller extent in underground caverns. Research is needed regarding the use of underground storage facilities to assess contamination considerations, volume and speed of discharge. Storage and transportation of gaseous fuels are generally more challenging than liquid ones due to their lower energy densities. Options such as compression and liquefaction of hydrogen are currently under assessment to improve energy density. Hydrogen molecules are particularly small compared to other gases which makes their storage more difficult as they leak more readily from storage containers. Ways to incorporate hydrogen into larger molecules via chemical reactions is one of the options being assessed. Absorption of hydrogen into solid-state compounds such as metal hydrides is suggested to be the safest and most convenient method of storage (Rusman and Dahari, 2016) due to their low pressure requirements and their ability to operate over extended time periods without hydrogen release (von Colbe et al., 2019). Much research is focused on the synthesis of metal hydrides having low absorption/desorption temperatures, high hydrogen storage densities, low costs, good cyclability, good resistance to oxidation, and moderate thermodynamic stability (Ren et al., 2017; Rusman and Dahari, 2016; von Colbe et al., 2019). Among metal hydrides, sodium borohydride $\left(\mathrm{NaBH}_{4}\right)$ and the mixture of borohydrides with other metal hydrides such as $\mathrm{MgH}_{2}$ are two of the most promising and investigated groups (Andersson and Grönkvist, 2019). In contrast, chemical hydrides such as methanol, ammonia and formic acid have much higher storage densities compared to metal hydrides. Much research on both chemical and metal hydride storage systems is needed to determine optimal large-scale layouts for hydrogen storage systems (Andersson and Grönkvist, 2019).

Hydrogen can used as a carrier to deliver energy to users or as an alternative fuel for transportation. Currently it is transported using trucks, railcars and ships. To be used in large scale in the future as an energy carrier, a dedicated hydrogen infrastructure may need to be built, the cost of which impacts the economic feasibility of using hydrogen. Blending hydrogen in natural gas pipeline networks is an option which may have less investment costs compared to a dedicated transmission and distribution infrastructure for hydrogen (Ogden et al., 2018). Research is focused on processes for mixing and separation of hydrogen before and after transmission, respectively (Nayebossadri et al., 2019). In general, transmission of hydrogen faces similar issues related to leakage and safety as its storage (Messaoudani et al., 2016). To avoid such challenges can add to the costs of hydrogen use as an energy carrier (by up to three times its production cost) where there is a long distance between its production plant and energy users (Kuang et al., 2016). Muradov and Veziroglu (2008) propose a transition from the current fossil-fuel based energy system to a hydrogen economy that allows exploitation of an existing energy infrastructure without significant environmental impacts.

Amoo and Fagbenle (2014) review the current energy situation in Nigeria, from the perspective of a hydrogen economy, considering its potential and implications. They examine options for hydrogen production from renewable energy and fossil fuels as well as issues and constraints (e.g., population growth, urbanisation and transportation limitations), and describe a future hydrogen economy having zero or near zero-carbon emissions. 


\section{ASSESSMENTS, COMPARISONS AND PLANNING FOR RENEWABLE ENERGY OPTIONS}

Policy options to support renewable energy require a holistic approach, in which technical, social and economic considerations are accounted for. Assessments and comparisons of various renewable energy source options are now reviewed in terms of these factors.

\section{Technical Performance}

Numerous technical and performance facets of various renewable energy options are reviewed, with particular attention paid to assessments of renewable energy source availability, evaluations of centralized and decentralized renewable energy options, and techno-economic examinations of hybrid renewable energy systems. Detailed technical aspects of $100 \%$ renewable energy systems are described by Mathiesen et al. (2011).

Higher penetration of renewable energy systems is directly affected by advancement of the technology and the development of skill to design, develop, locally manufacture, install, operate and maintain the technology (Yaqoot et al., 2016). For example, too complex or faulty designs, lack of standards, codes and certifications, poor reliability and improper installation are reported as significant barriers to development of solar and wind energy technologies in some cases (Yaqoot et al., 2016).

There are many classifications related to the use of decentralized power. These classifications and the available technological alternatives complicate efforts to prioritize decentralized power options. Kaundinya et al. (2009) present characteristics of several decentralized power alternatives, including details on modeling and analysis of technological, environmental and economic aspects and potentials of stand-alone and grid-connected options for decentralized power.

Lack of continuous resource availability is an important factor hindering the development of some types of renewable energy resources. This especially impacts development of decentralized systems and necessitates energy storage use to improve the energy availability of various energy resources. Integration of multiple energy systems is another option to overcome the intermittency challenge. Angelis-Dimakis et al. (2011) review available tools and methods to determine exploitable and potential renewable energy, highlighting the challenges for each, and describe tools for assessing the utilization of a mix of sources. Connolly et al. (2010) review computational tools for analyzing the integration of applications with renewable energy, and provides the information needed for identifying a suitable energy tool for assessing the integration of renewable energy with several energy systems, for various objectives.

Solar and wind energy are often viewed globally as the two most viable renewable energy resources, in part because their characteristics are somewhat complementary, and can be incorporated in hybrid solar-wind systems. Yang et al. (2009) propose an optimal method for hybrid solar-wind system design using five decision variables: number of wind turbines, wind turbine height and battery capacity, number of PV panels, and PV panel slope angle.

Pöschl et al. (2010) investigate various biogas usage paths, the energy efficiency of various biogas systems, including co- and single-digestion of multiple feedstocks, and strategies for waste-stream management, using as input data process management information on anaerobic digestion and assessments of actual biogas systems.

Baños et al. (2011) review computational optimization methods for renewable and sustainable energy and their current statuses, and describe recent research advances in this field.

\section{Economics}

Electricity generation from renewable energy resources as an option to mitigate GHG emissions has received increased interest over the past decades. Therefore, it is important to understand the economics of their utilization as well as broader economic impacts on society. An analysis of the design of a complete renewable energy system including transportation shows that implementing renewable energy, as well as energy conservation and efficiency measures, can create employment, and yield positive socio-economic effects and export earnings (Mathiesen et al., 2011). An investigation into the efficiency of various schemes for renewable energy utilization from theoretical and practical viewpoints (i.e., by examining concrete examples of implementation schemes) highlights the high efficiency of a system of feed-in-tariffs and the theoretical interest in green certificate trading (Menanteau et al., 2003). Varun et al. (2009) examine renewable technologies for electricity generation for numerous sustainability indicators: GHG emissions, payback period, electricity generation cost, while Akella et al. (2009) investigate factors having economic, social and environmental effects linked to using renewable energy instead of conventional energy systems. Stougie et al. (2018) perform an economic sustainability assessment of five power generation systems: a photovoltaic park, an offshore wind farm, a biomass-fired power plant, and coal-fired power plants (with and without carbon capture and storage). They conclude that the three renewable energy systems require subsidies to be profitable. The coal power plant with carbon capture and storage also depends on credits from selling $\mathrm{CO}_{2}$ emission rights to be profitable. Connolly et al. (2016) perform an economic assessment of a Smart Energy Europe scenario and compare it to a business-as-usual scenario. They find a $10-15 \%$ increase in the cost of the proposed scenario that would end in a 100\% renewable energy penetration in Europe and suggest that the economic benefits of such a scenario are greater due to its potential for creating in the European Union ten million extra direct jobs. Another analysis of the potential to use renewable energy systems to meet electricity demand of cities fully or even partially (e.g., by satisfying demands at only specific fractions of the time) suggests that to reach economic feasibility integration is necessary between thermal, electrical, transport, and other sectors (Narayanan et al., 2019).

High initial capital costs are attributed to many renewable energy systems and as a result slow their development due to poor purchasing power of energy users and long payback periods. Other costs such as those of conventional fuels and operation and maintenance as well as transaction costs related to renewable energy projects compared to fossil fuel energy systems, have also 
Table 3. Factors impacting public perception of wind farms, broken down by category (adapted from Devine-Wright, 2005)

\begin{tabular}{ll}
\hline Perception category & Factor \\
\hline Physical & Wind turbine physical characteristics (colour, size, acoustics, etc.) \\
\hline Geographic & $\begin{array}{l}\text { Wind farm physical characteristics (size, shape, acoustics, etc.) } \\
\text { Proximity to wind farm/turbines of people } \\
\text { Landscape in which wind farm/turbines are located }\end{array}$ \\
\hline Institutional & Institutional capacity \\
\hline Political & Policy support \\
& Political support and interests \\
\hline Social and socio-economic & Communication \\
& Social influences (social networks, media, trust) \\
& Public participation and consultation \\
\hline Local & Shareholding \\
\hline Personal & Location and identity \\
\hline Symbolic and ideological & Community or local control and benefit \\
\hline & NIMBYism \\
\hline & Previous knowledge and experience \\
\hline
\end{tabular}

been reported for some renewable energy technologies in some regions (Ouedraogo, 2019; Yaqoot et al., 2016). In regions where fossil fuels are more abundant and cheaper than alternative sources of energy, renewable energy systems may not become financially feasible unless other factors promoting the utilization of renewable energy sources like technology incentives (e.g., capital subsidies and soft loans) or carbon credits are introduced. Such analyses often do not account for external costs, such as environmental and health-related costs. Inclusion of such external costs of energy in financial feasibility analyses (e.g., environment cost) are recommended for reducing the payback period of such systems and their expansion (Yaqoot et al., 2016). Removal of subsidies to fossil fuels and introducing taxes and tariffs that assist expansion of renewable energy technologies, access to credit facilities and investment support are other options that may be needed.

\section{Social Acceptance}

While many countries have targets, sometimes ambitious, to increase the renewable energy share in the energy supply, it is recognised increasingly that lack of public acceptance and social "disengagement of energy users" (Heldeweg and Saintier, 2020) often pose barriers to renewable energy development.

Lack of public acceptance is often caused by a lack of information and/or economical barriers of renewable energy technologies (discussed in the section Economics). This is particularly so for wind turbines because of their visual appearance on landscapes (Devine-Wright, 2005; Wüstenhagen et al., 2007). Local community participation and increasing awareness are suggested to increase employment of decentralized renewable energy systems as well since they might positively impact users' perception of financial and investment risk of renewable energy system installation. Bayulgen and Benegal (Bayulgen and Benegal, 2019) suggest that the use of various economic frames in communication of the values of renewable energy to people could affect peoples' decisions. They suggest the use of frames that emphasize personal economic gains of renewable energy systems more directly. Other factors such as users' spending priorities have also been mentioned as impacting the use of renewable energy technologies in some regions (Yaqoot et al., 2016). In moving towards energy sustainability, improving socioeconomic acceptability is an important parameter, and includes economic affordability, social acceptability, community involvement, and land use, lifestyle, equity and aesthetics (Rosen, 2009). Increased informed empirical research, founded on the social sciences and relevant methods and concepts, is required to explain perceptual processes. Several studies provide insights into how renewable energy sources are perceived by the public (Bailey et al., 2011; Devine-Wright, 2005; Wüstenhagen et al., 2007).

Based on reviews of research on public perceptions of wind energy, Devine-Wright (2005) assesses prior research critically and provides a multidimensional and integrated framework as a guide to future research. Note that opposition typically is characterized by the concept of NIMBY (not in my back yard). Six distinct research strands are summarized and assessed: effects of physical proximity to turbines, public support for switching from conventional to wind energy sources, wind turbine factors associated with negative perceptions, wind farm acceptance over time, NIMBY as the cause of negative perceptions, and the impact on perceptions of local involvement (Table 3).

Factors affecting community and socio-political acceptance are important for comprehending the current contradiction between lack of renewable energy progress and public support for renewable energy and related innovation. Market acceptance is another dimension which has received inadequate attention and is in need of further research. Wüstenhagen et al. (2007) introduce aspects of social acceptance and cite numerous investigations focused on these areas.

Building renewable energy facilities off shore seemingly reduces social tension. However, research on public perceptions of marine renewable energy is limited, such as wave and tidal power, and is needed to understand how such developments are or are not supported in actuality. Bailey et al. (2011) investigate public opinions on a coastal site presently under construction in the southwest UK for wave energy and examine dynamics in public attitudes regarding future technologies for renewable energy such as wave energy (Table 4). 
Table 4. Unpredictability of public attitudes towards renewable energy installation (adapted from Bailey et al., 2011)

\begin{tabular}{lll}
$\begin{array}{l}\text { Project development } \\
\text { stage }\end{array}$ & $\begin{array}{l}\text { Shift in support level by } \\
\text { residents }\end{array}$ & Possible causes \\
\hline Initial proposal & Rise & $\begin{array}{l}\text { Clean energy } \\
\text { Local economic benefits }\end{array}$ \\
\hline Proposal submission & Drop & $\begin{array}{l}\text { Installation occurs near communities } \\
\text { Construction creates disruption in transport links, local industries and landscape quality }\end{array}$ \\
\hline Installation complete & Rise & $\begin{array}{l}\text { Less negative impacts than expected } \\
\text { Economic benefits begin to be recognised by residents }\end{array}$ \\
\hline After completion & Drop & $\begin{array}{l}\text { Occurrence of adverse surprises (e.g. wildlife harm) } \\
\text { Less-than-expected economic benefits }\end{array}$ \\
\hline & Rise & $\begin{array}{l}\text { Effective management of adverse surprises } \\
\text { More economic benefits than expected }\end{array}$ \\
\hline
\end{tabular}

\section{Renewable Energy Planning and Policies}

Energy planning and policies play a key role in transitioning to increased or even $100 \%$ renewable energy provision. To achieve public support, processes that allow stakeholder participation may be implemented and diverse stakeholders' rationales may be reviewed. Since economic growth and energy use are closely linked and are greatly impacted by available energy policy programs, in providing policies for transitioning to higher use of renewable energy technologies while ensuring economic growth, analysis is needed of the relation of economic growth to non-renewable and renewable electricity consumption. Such analyses of OECD countries show that policies for renewable energies need examination regarding not only economic growth, but also enhancing electricity environmental characteristics and supply security (Aydin, 2019). A study of South Asian countries shows the effect on economic growth of renewable energy usage to be much stronger than that of non-renewable energy (Rahman and Velayutham, 2020). Energy policy plays a vital role in increasing utilization of environmentally friendly energy alternatives and in sustaining and increasing demand for renewable energy, mainly by addressing the economic barriers that are mentioned in the section Economics. Long-term policies, appropriate regulatory frameworks, development of the needed infrastructure and cooperation with international agencies are some ways renewable energy technology use may increase. Policies that support increased renewable energy technology use include elimination of current fossil fuel subsidies and policies that favor established systems like large fossil-fired power plants, provision to users of fiscal incentives, and establishment and/or support of research and development centres (Yaqoot et al., 2016). Policies are also needed to avoid the negative impacts of renewable energy market size and structure. The smaller size of renewable energy technologies, especially decentralized systems, and subsequent lack of economies of scale often is an economic barrier to their growth (Yaqoot et al., 2016). Three main technological factors are typically involved in making strategies for sustainable development: energy production efficiency improvement, demand side energy savings, and fossil fuel substitutions with renewable energy sources to convert to high or even $100 \%$ renewable energy. Enhancements in energy production efficiency include strategic use of technologies that facilitate renewable energy use (see the section Energy Technologies that Facilitate Renewable Energy Use) such as energy storage systems (Debia et al., 2019). Implementation plans for large-scale renewable energy employment require strategies for integrating renewable sources into energy systems coherently, accounting for conservation and efficiency measures.

Perspectives on converting energy systems to $100 \%$ renewable and problems associated with such a goal are often studied (Lund, 2007). Capacity building, resource assessment, quality control, standardization and research and development and are needed to increase the renewable energy technology share (Yaqoot et al., 2016). In such energy planning, flexible energy system technologies and technologies for converting the transportation sector are important (Hansen et al., 2019). A recent study suggests a transition to $100 \%$ renewable energy technologies is economically feasible in Germany. However, achieving such a transition may push biomass resources to the maximum of their defined constraints (Hansen et al., 2019). The history of energy and power, including past limitations, and possible future developments are reviewed by Wilson (2012), and an idealized energy policy is proposed.

By reviewing existing energy policies for selected countries, Saidur et al. (2010) explore the wind energy industry from a policy perspective, and identify pricing laws, incentives, and quota systems as some of the most advantageous energy policies globally.

Solangi et al. (2011) review various existing solar energy policies implemented around the world. Sener and Fthenakis (2014) review and assess public-policy options in the United States for supporting large-scale PV penetration, and investigate existing energy-policy mixes in countries that lead to solar energy developments, identify areas for improvement in the existing policy mix in the United States and highlight lessons learned.

\section{CONCLUSION}

A critical review and overview of renewable energy is provided, including renewable energy categorizations, comparisons and applications, as well as recent advances and research directions. The renewable energy technologies covered include solar, wind, geothermal, bio, waste-derived, hydraulic, wave, tidal, and ocean thermal. Furthermore, technologies facilitating renewable energy use are described such as multigeneration, integrated energy systems, district energy, energy storage, and hydrogen and fuel cell systems. Some studies focus on reducing energy consumption of existing energy systems, while others focus on the development of new sources of renewable energy (e.g. new sources of bioenergy) and designing new technologies to exploit 
renewable energies (e.g. ocean renewable energies) or improving existing technologies (e.g. solar PV). The integration of current fossil fuel energy systems with renewable energy systems to bridge the divide between existing energy systems and $100 \%$ renewable energy systems has also received attention. Limitations on growth of renewable energy systems are linked to various factors, including availability of renewable energy sources, challenges with technologies that are able to exploit these energies and provide them when the user demands, costs, and their public perceptions. Much research and development on such aspects remains needed to move towards sustainable energy systems.

\section{REFERENCES}

Abbasi, T. and Abbasi, S. A. (2010). Biomass energy and the environmental impacts associated with its production and utilization. Renew Sust Energ Rev, 14(3), 919-937. https://doi.org/10.1016/j.rser.2009.11.006

Abbasi, T. and Abbasi, S. A. (2012). Is the use of renewable energy sources an answer to the problems of global warming and pollution?. Crit Rev Env Sci Technol, 42(2), 99-154. https://doi.org/10.1080/10643389.2010.498754

Ahmadi, P., Dincer, I. and Rosen, M. A. (2013). Energy and exergy analyses of hydrogen production via solar-boosted ocean thermal energy conversion and PEM electrolysis. Int J Hydrogen Energ, 38(4), 1795-1805. https://doi.org/10.1016/j.ijhydene.2012.11.025

Akella, A. K., Saini, R. P. and Sharma M. P. (2009). Social, economical and environmental impacts of renewable energy systems. Renew Energ, 34(2), 390-396. https://doi.org/10.1016/j.renene.2008.05.002

Al Seadi, T. (2002). Quality management of AD residues from biogas production. IEA Bioenergy, Task 24-Energy from Biological Conversion of Organic Waste, Jan 2002. Available at: www.IEA-Biogas.net

Alva, G., Liu, L., Huang, X. and Fang, G. (2017). Thermal energy storage materials and systems for solar energy applications. Renew Sust Energ Rev, 68(1), 693-706. https://doi.org/10.1016/j.rser.2016.10.021

Alvarez, R. and Liden, G. (2008). Semi-continuous co-digestion of solid slaughterhouse waste, manure, and fruit and vegetable waste. Renew Energ, 33, 726-734. https://doi.org/10.1016/j.renene.2007.05.001

Alvarez-Silva, O. A., Osorio, A. F. and Winter, C. (2016). Practical global salinity gradient energy potential. Renew Sust Energ Rev, 60, 1387-1395. https://doi.org/10.1016/j.rser.2016.03.021

Amoo, L. M. and Fagbenle, R. L. (2014). Hydrogen energy's key contributions to the sustainable energy mix of a low-carbon future in Nigeria. Int J Sust Energ, 33(4), 742-765. https://doi.org/10.1080/14786451.2013.765427

Andersen, A. N. and Østergaard, P. A. (2019). Analytic versus solver-based calculated daily operations of district energy plants. Energy, 175, 333-344. https://doi.org/10.1016/j.energy.2019.03.096

Andersson, J. and Grönkvist, S. (2019). Large-scale storage of hydrogen. Int J Hydrogen Energ, 44(23), 11901-11919. https://doi.org/10.1016/j.ijhydene.2019.03.063

Angelis-Dimakis, A., Biberacher, M., Dominguez, J., Fiorese, G., Gadocha, S., Gnansounou, E., Guariso, G., Kartalidis, A., Panichelli, L., Pinedo, I. and Robba, M. (2011). Methods and tools to evaluate the availability of renewable energy sources. Renew Sust Energ Rev, 15(2), 1182-1200. https://doi.org/10.1016/j.rser.2010.09.049

Arevalo-Gallegos, A., Ahmad, Z., Asgher, M., Parra-Saldivar, R. and Iqbal, H. M. N. (2017). Lignocellulose: A sustainable material to produce value-added products with a zero waste approach-A review. International Journal of Biological Macromolecules, 99, 308-318. https://doi.org/10.1016/j.ijbiomac.2017.02.097

Armaroli, N. and Balzani, V. (2007). The future of energy supply: challenges and opportunities. Angew. Chem Int, 46, 52-66. https://doi.org/10.1002/anie.200602373

Armaroli, N. and Balzani, V. (2016). Solar electricity and solar fuels: status and perspectives in the context of the energy transition. Chemistry - A European Journal, 22, 32-57. https://doi.org/10.1002/chem.201503580

Asdrubali, F., Baldinelli, G., D'Alessandro, F. and Scrucca, F. (2015). Life cycle assessment of electricity production from renewable energies: Review and results harmonization. Renew Sust Energ Rev, 42, 1113-1122. https://doi.org/10.1016/j.rser.2014.10.082

Aydin, M. (2019). Renewable and non-renewable electricity consumption-economic growth nexus: Evidence from OECD countries. Renew Energ, 136, 599-606. https://doi.org/10.1016/j.renene.2019.01.008

Ayres, R. U., Turton, H. and Casten, T. (2007). Energy efficiency, sustainability and economic growth. Energy, 32(5), 634-648. https://doi.org/10.1016/j.energy.2006.06.005

Azhar, M. S., Rizvi, G. and Dincer, I. (2017). Integration of renewable energy based multigeneration system with desalination. Desalination, 404, 72-78. https://doi.org/10.1016/j.desal.2016.09.034

Bahaj, A. S. (2011). Generating electricity from the oceans. Renew Sust Energ Rev, 15, 3399-3416. https://doi.org/10.1016/j.rser.2011.04.032

Bailey, I., West, J. and Whitehead, I. (2011). Out of sight but not out of mind? Public perceptions of wave energy. J Environ Policy Plan, 13(2), 139-157. https://doi.org/10.1080/1523908X.2011.573632

Bajpai, P. and Dash, V. (2012). Hybrid renewable energy systems for power generation in stand-alone applications: a review. Renew Sust Energ Rev, 16, 2926-2939. https://doi.org/10.1016/j.rser.2012.02.009

Balat, M. and Balat, H. (2009). Biogas as a renewable energy source-a review. Energ Source, Part A, 31, $1280-1293$. https://doi.org/10.1080/15567030802089565 
Baños, R., Manzano-Agugliaro, F., Montoya, F. G., Gila, C., Alcayde, A. and Gómez, J. (2011). Optimization methods applied to renewable and sustainable energy: a review. Renew Sust Energ Rev, 15(4), $1753-1766$. https://doi.org/10.1016/j.rser.2010.12.008

Bartolozzi, I., Rizzi, F. and Frey, M. (2017). Are district heating systems and renewable energy sources always an environmental win-win solution? A life cycle assessment case study in Tuscany, Italy. Renew Sust Energ Rev, 80, $408-420$. https://doi.org/10.1016/j.rser.2017.05.231

Bayon, A., Bader, R., Jafarian, M., Fedunik-Hofman, L., Sun, Y., Hinkley, J., Miller, S. and Lipiński, W. (2018). Techno-economic assessment of solid-gas thermochemical energy storage systems for solar thermal power applications. Energy, 149, 473-484. https://doi.org/10.1016/j.energy.2017.11.084

Bayulgen, O. and Benegal, S. (2019). Green Priorities: How economic frames affect perceptions of renewable energy in the United States. Energ Res Soc Sci, 47, 28-36. https://doi.org/10.1016/j.erss.2018.08.017

Beran, L. and Dyckhoff, H. (2019). Global Biomass Supply and Sustainable Development. In: M. Behnassi, H. Gupta and O. Pollmann (eds), Human and Environmental Security in the Era of Global Risks (pp. 291-316). Springer, Cham. https://doi.org/10.1007/9783-319-92828-9_15

Bouraiou, A., Necaibia, A., Boutasseta, N., Mekhilef, S., Dabou, R., Ziane, A., et al. (2020). Status of renewable energy potential and utilization in Algeria. J Cleaner Production, 246, 119011. https://doi.org/10.1016/j.jclepro.2019.119011

Breton, S. P. and Moe, G. (2009). Status, Plans and technologies for offshore wind turbines in Europe and North America. Renew Energ, 34, 646-654. https://doi.org/10.1016/j.renene.2008.05.040

Brouwer, J. (2010). On the role of fuel cells and hydrogen in a more sustainable and renewable energy future. Curr Appl Phys, 10(2), 9-17. https://doi.org/10.1016/j.cap.2009.11.002

Campos-Guzmán, V., García-Cáscales, M. S., Espinosa, N. and Urbina, A. (2019). Life Cycle Analysis with Multi-Criteria Decision Making: A review of approaches for the sustainability evaluation of renewable energy technologies. Renew Sust Energ Rev, 104, 343-366. https://doi.org/10.1016/j.rser.2019.01.031

Carlino, S., Somma, R., Troise, C. and De Natale, G. (2012). The geothermal exploration of Campanian volcanoes: historical review and future development. Renew Sust Energ Rev, 16(1), 1004-1030. https://doi.org/10.1016/j.rser.2011.09.023

Carrasco, J. M., Franquelo, L. G., Bialasiewicz, J. T., Galván, E., Guisado, R. C. P., Prats, M. A. M., Leon, J. I. and Moreno-Alfonso, N. (2006). Power-electronic systems for the grid integration of renewable energy sources: a survey. IEEE TInd Electron, 53(4), 10021016. https://doi.org/10.1109/TIE.2006.878356

Cavallo, A. (2007). Controllable and affordable utility-scale electricity from intermittent wind resources and compressed air energy storage (CAES). Energy, 32, 120-127. https://doi.org/10.1016/j.energy.2006.03.018

Chamandoust, H., Derakhshan, G., Hakimi, S. M. and Bahramara, S. (2020). Tri-objective scheduling of residential smart electrical distribution grids with optimal joint of responsive loads with renewable energy sources. J Energ Storage, $27,101112$. https://doi.org/10.1016/j.est.2019.101112

Chingulpitak, S. and Wongwises, S. (2014). Critical review of the current status of wind energy in Thailand. Renew Sust Energ Rev, 31(3), 312-318. https://doi.org/10.1016/j.rser.2013.11.038

Chu, S. and Majumdar, A. (2012). Opportunities and challenges for a sustainable energy future. Nature, 488, $294-303$. https://doi.org/10.1038/nature11475

Clauser, C. and Ewert, M. (2018). The renewables cost challenge: Levelized cost of geothermal electric energy compared to other sources of primary energy - Review and case study. Renew Sust Energ Rev, 82(3), $3683-3693$. https://doi.org/10.1016/j.rser.2017.10.095

Collet, P., Hélias, A., Lardon, L., Ras, M., Goy, R. A. and Steyer, J. P. (2011). Life-cycle assessment of microalgae culture coupled to biogas production. Bioresource Technol, 102, 207-214. https://doi.org/10.1016/j.biortech.2010.06.154

Connolly, D., Lund, H. and Mathiesen, B. V. (2016). Smart Energy Europe: The technical and economic impact of one potential 100\% renewable energy scenario for the European Union. Renew Sust Energ Rev, 60, 1634-1653. https://doi.org/10.1016/j.rser.2016.02.025

Connolly, D., Lund, H., Mathiesen, B. V. and Leahy, M. (2010). A review of computer tools for analysing the integration of renewable energy into various energy systems. Appl Energ, 87(4), 1059-1082. https://doi.org/10.1016/j.apenergy.2009.09.026

Cuomo, M. A., Kool, E. D., Reddy, B. V. and Rosen, M. A. (2018). Energy modelling and analysis of a multi-generation renewable energy system for dairy farm applications. Biofuels. Published online: 28 May 2018. https://doi.org/10.1080/17597269.2018.1469342

Darwish, M., Mohtar, R., Elgendy, Y. and Chmeissani, M. (2012). Desalting seawater in Qatar by renewable energy: a feasibility study. Desalin Water Treat, 47(1-3), 279-294. https://doi.org/10.1080/19443994.2012.696409

de Fraiture, C., Giordano, M. and Liao, Y. (2008). Biofuels and implications for agricultural water use: blue impacts of green energy. Water Policy, 10(1), 67-81. https://doi.org/10.2166/wp.2008.054

de O. Falcão, A. F. (2010). Wave energy utilization: A review of the technologies. Renew Sust Energ Rev, 14(3), $899-918$. https://doi.org/10.1016/j.rser.2009.11.003 
Debia, S., Pineau, P. O. and Siddiqui, A. S. (2019). Strategic use of storage: The impact of carbon policy, resource availability, and technology efficiency on a renewable-thermal power system. Energy Economics, 80, $100-122$. https://doi.org/10.1016/j.eneco.2018.12.006

Deshmukh, M. K. and Deshmukh, S. S. (2008). Modeling of hybrid renewable energy systems. Renew Sust Energ Rev, 12(1), $235-249$. https://doi.org/10.1016/j.rser.2006.07.011

Desholm, M. and Kahlert, J. (2005). Avian collision risk at an offshore wind farm. Biol. Lett., 1(3), $296-298$. https://doi.org/10.1098/rsbl.2005.0336

Devine-Wright, P. (2005). Beyond NIMBYism: towards an integrated framework for understanding public perceptions of wind energy. Wind Energ, 8(2), 125-139. https://doi.org/10.1002/we.124

Dhyani, V. and Bhaskar, T. (2018). A comprehensive review on the pyrolysis of lignocellulosic biomass. Renew Energ, 129(B), 695716. https://doi.org/10.1016/j.renene.2017.04.035

Díaz-González, F., Sumper, A., Gomis-Bellmunt, O. and Villafáfila-Robles, R. (2012). A review of energy storage technologies for wind power applications. Renew Sust Energ Rev, 16, 2154-2171. https://doi.org/10.1016/j.rser.2012.01.029

Edwards, P. P., Kuznetsov, V. L., David, W. I. F. and Brandon, N. P. (2008). Hydrogen and fuel cells: towards a sustainable energy future. Energ Policy; 36, 4356-4362. https://doi.org/10.1016/j.enpol.2008.09.036

Eriksson, E. L. V. and Gray, E. M. A. (2017). Optimization and integration of hybrid renewable energy hydrogen fuel cell energy systems - A critical review. Appl Energ, 202, 348-364. https://doi.org/10.1016/j.apenergy.2017.03.132

Evans, A., Strezov, V. and Evans, T. J. (2019). Assessment of sustainability indicators for renewable energy technologies. Renew Sust Energ Rev, 13(5), 1082-1088. https://doi.org/10.1016/j.rser.2008.03.008

Fedak, W., Anweiler, S., Ulbrich, R. and Jarosz, B. (2017). The concept of autonomous power supply system fed with renewable energy sources. Journal of Sustainable Development of Energy, Water and Environment Systems, 5(4), 579-589. https://doi.org/10.13044/j.sdewes.d5.0160

Fox, A. D., Desholm, M., Kahlert, J., Christensen, T. K. and Petersen, I. B. K. (2006). Information needs to support environmental impact assessment of the effects of European marine offshore wind farms on birds. Ibis, 148, $129-144$. https://doi.org/10.1111/j.1474-919X.2006.00510.x

Franchini, G., Brumana, G. and Perdichizzi, A. (2018). Performance prediction of a solar district cooling system in Riyadh, Saudi Arabia - A case study. Energy Conversion and Management, 166, 372-384. https://doi.org/10.1016/j.enconman.2018.04.048

Gallup, D. L. (2009). Production engineering in geothermal technology: a review. Geothermics, 38(3), 326-334. https://doi.org/10.1016/j.geothermics.2009.03.001

Gollakota, A. R. K., Kishore, N. and Gu, S. (2018). A review on hydrothermal liquefaction of biomass. Renew Sust Energ Rev, 81(1), 1378-1392. https://doi.org/10.1016/j.rser.2017.05.178

Hallenbeck, P. C. (2011). Microbial paths to renewable hydrogen production. Biofuels, 2(3), $285-302$. https://doi.org/10.4155/bfs.11.6

Hansen, K., Mathiesen, B. V. and Skov, I. R. (2019). Full energy system transition towards 100\% renewable energy in Germany in 2050. Renew Sust Energ Rev, 102, 1-13. https://doi.org/10.1016/j.rser.2018.11.038

Hanson, H. P., Bozec, A. and Duerr, A. E. S. (2011). The Florida Current: A clean but challenging energy resource. Transactions of the American Geophysical Union, 92, 29-30. https://doi.org/10.1029/2011E0040001

Heldeweg, M. A. and Saintier, S. (2020). Renewable energy communities as 'socio-legal institutions': A normative frame for energy decentralization? Renew Sust Energ Rev, 119, 109518. https://doi.org/10.1016/j.rser.2019.109518

Hemmati, R. (2017). Technical and economic analysis of home energy management system incorporating small-scale wind turbine and battery energy storage system. Journal of Cleaner Production, 159, 106-118. https://doi.org/10.1016/j.jclepro.2017.04.174

Hepbasli, A. (2008). A key review on exergetic analysis and assessment of renewable energy resources for a sustainable future. Renew Sust Energ Rev, 12, 593-661. https://doi.org/10.1016/j.rser.2006.10.001

Herbert, G. M. J., Iniyan, S., Sreevalsan, E. and Rajapandian, S. (2007). A review of wind energy technologies. Renew Sust Energ Rev, 11, 1117-1145. https://doi.org/10.1016/j.rser.2005.08.004

Hertwich, E. G., Gibon, T., Bouman, E. A., Arvesen, A., Suh, S., Heath, G. A., Bergesen, J. D., Ramirez, A., Vega, M. I. and Shi, L. (2015). Integrated life-cycle assessment of electricity-supply scenarios confirms global environmental benefit of low-carbon technologies. PNAS, 112(20), 6277-6282. https://doi.org/10.1073/pnas.1312753111

Holm-Nielsen, J. B., Al Seadi, T. and Oleskowicz-Popiel, P. (2009). The future of anaerobic digestion and biogas utilization. Bioresource Technol, 100, 5478-5484. https://doi.org/10.1016/j.biortech.2008.12.046

Hosseini, M., Dincer, I. and Rosen, M. A. (2014). Investigation of a hybrid photovoltaic-biomass system with energy storage options. J Sol Energ Eng, 136(3), 034504. https://doi.org/10.1115/1.4026637

Hosseini, S. E. and Wahid, M. A. (2016). Hydrogen production from renewable and sustainable energy resources: Promising green energy carrier for clean development. Renew Sust Energ Rev, 57, 850-866. https://doi.org/10.1016/j.rser.2015.12.112

Huen, P. and Daoud, W. A. (2017). Advances in hybrid solar photovoltaic and thermoelectric generators. Renew Sust Energ Rev, 72 , 1295-1302. https://doi.org/10.1016/j.rser.2016.10.042 
Hussain, A., Arif, S. M. and Aslam, M. (2017). Emerging renewable and sustainable energy technologies: State of the art. Renew Sust Energ Rev, 71, 12-28. https://doi.org/10.1016/j.rser.2016.12.033

Inayat, A. and Raza, M. (2019). District cooling system via renewable energy sources: A review. Renew Sust Energ Rev, 107, $360-373$. https://doi.org/10.1016/j.rser.2019.03.023

Infield, D. and Freris, L. (2020). Renewable Energy in Power Systems. John Wiley \& Sons.

Inger, R., Attrill, M. J., Bearhop, S., Broderick, A. C., Grecian, W. J., Hodgson, D. J., et al. (2009). Marine renewable energy: potential benefits to biodiversity? An urgent call for research. J Appl Ecol, 46, 1145-1153. https://doi.org/10.1111/j.13652664.2009.01697.x

International Energy Agency. Energy technology perspectives (2010). 2010: Scenarios and strategies to 2050. Report, IEA, Paris.

International Renewable Energy Agency, Ocean Thermal Energy Conversion, Technical brief; 2014.

Jacobson, M. Z. (2009). Review of solutions to global warming, air pollution, and energy security. Energy Environ Sci, 2, $148-173$. https://doi.org/10.1039/B809990C

Jain, C., Vogt, C. and Clauser, C. (2015). Maximum potential for geothermal power in Germany based on engineered geothermal systems. Geotherm Energy, 3, 15-35. https://doi.org/10.1186/s40517-015-0033-5

Jørgensen, C. L., Clausen, L. R., Algren, L., Hansen, A. B., Münster, M., Gadsbøll, R. Ø. And Haglind, F. (2017). Optimization of a flexible multi-generation system based on wood chip gasification and methanol production. Appl Energ, 192, 337-359. https://doi.org/10.1016/j.apenergy.2016.08.092

Jørgensen, C. L., Ensinas, A. V., Münster, M. and Haglind, F. (2016). A methodology for designing flexible multi-generation systems. Energy, 110, 34-54. https://doi.org/10.1016/j.energy.2016.01.084

Kabalina, N., Costa, M., Yang, W. and Martin, A. (2017). Energy and economic assessment of a polygeneration district heating and cooling system based on gasification of refuse derived fuels. Energy, 137, 696-705. https://doi.org/10.1016/j.energy.2017.06.110

Kaldellis, J. K. and Zafirakis, D. (2007). Optimum energy storage techniques for the improvement of renewable energy sourcesbased electricity generation economic efficiency. Energy, 32, 2295-2305. https://doi.org/10.1016/j.energy.2007.07.009

Kaundinya, D. P., Balachandra, P. and Ravindranath, N. H. (2009). Grid-connected versus stand-alone energy systems for decentralized power-a review of literature. Renew Sust Energ Rev, 13(8), 2041-2050. https://doi.org/10.1016/j.rser.2009.02.002

Kaygusuz, K. (2009). Wind power for a clean and sustainable energy future. Energ Source, Part B, 4(1), $122-133$. https://doi.org/10.1080/15567240701620390

Khare, V., Nema, S. and Baredar, P. (2016). Solar-wind hybrid renewable energy system: A review. Renew Sust Energ Rev, 58, $23-33$. https://doi.org/10.1016/j.rser.2015.12.223

Koohi-Fayegh, S. and Rosen, M. A. (2020). A review of energy storage types, applications and recent developments. J Energ Storage, 27, 101047. https://doi.org/10.1016/j.est.2019.101047

Koračin, D., Belu, R., Canadillas, B., Horvath, K., Vellore, R., Smith, C., Jiang, J. and Mccord, T. (2012). A review of challenges in assessment and forecasting of wind energy resources. Croatian Meteorological J, 47, 13-33.

Kothari, R., Tyagi, V. V. and Pathak, A. (2010). Waste-to-energy: a way from renewable energy sources to sustainable development. Renew Sust Energ Rev, 14, 3164-3170. https://doi.org/10.1016/j.rser.2010.05.005

Kuang, Y., Zhang, Y., Zhou, B., Li, C., Cao, Y., Li, L. and Zeng, L. (2016). A review of renewable energy utilization in islands. Renew Sust Energ Rev, 59, 504-513. https://doi.org/10.1016/j.rser.2016.01.014

Kumar, R. and Rosen, M. A. (2011). A critical review of photovoltaic-thermal solar collectors for air heating. Appl Energ, 88(11), 36033614. https://doi.org/10.1016/j.apenergy.2011.04.044

Lewis, N. S. (2016). Research opportunities to advance solar energy utilization. Science, 351(6271), 1920. https://doi.org/10.1126/science.aad1920

Lewis, N. S. and Nocera, D. G. (2006). Powering the planet: Chemical challenges in solar energy utilization. PNAS, 103, $15729-15735$. https://doi.org/10.1073/pnas.0603395103

Liserre, M., Sauter, T. and Hung, J. Y. (2010). Future energy systems: integrating renewable energy sources into the smart power grid through industrial electronics. IEEE Ind Electron Mag, 4(1), 18-37. https://doi.org/10.1109/MIE.2010.935861

Liu, M., Steven Tay, N. H., Bell, S., Belusko, M., Jacob, R., Will, G., Saman, W. and Bruno, F. (2016). Review on concentrating solar power plants and new developments in high temperature thermal energy storage technologies. Renew Sust Energ Rev, 53, 1411-1432. https://doi.org/10.1016/j.rser.2015.09.026

Lu, S. M. (2018). A global review of enhanced geothermal system (EGS). Renew Sust Energ Rev, 81(2), $2902-2921$. https://doi.org/10.1016/j.rser.2017.06.097

Lucia, U., Simonetti, M., Chiesa, G. and Grisolia, G. (2017). Ground-source pump system for heating and cooling: Review and thermodynamic approach. Renew Sust Energ Rev, 70, 867-874. https://doi.org/10.1016/j.rser.2016.11.268

Lund, H. (2007). Renewable energy strategies for sustainable development. Energy, 32(6), 912-919. https://doi.org/10.1016/j.energy.2006.10.017

Lund, H., Moller, B., Mathiesen, B. V. and Dyrelund, A. (2010). The role of district heating in future renewable energy systems. Energy, 35(3), 1381-1390. https://doi.org/10.1016/j.energy.2009.11.023 
Lund, H., Østergaard, P. A., Chang, M., Werner, S., Svendsen, S., Sorknæs, P., et al. (2018). The status of 4th generation district heating: Research and results. Energy, 164, 147-159. https://doi.org/10.1016/j.energy.2018.08.206

Lund, J. W. (2010). Direct utilization of geothermal energy. Energies, 3, 1443-1471. https://doi.org/10.3390/en3081443

Mathews, J. A. (2008). Carbon-negative biofuels. Energ Policy, 36(3), 940-945. https://doi.org/10.1016/j.enpol.2007.11.029

Mathiesen, B. V., Lund, H. and Karlsson, K. (2011). 100\% Renewable energy systems, climate mitigation and economic growth. Appl Energ, 88(2), 488-501. https://doi.org/10.1016/j.apenergy.2010.03.001

Menanteau, P., Finon, D. and Lamy, M. L. (2003). Prices versus quantities: choosing policies for promoting the development of renewable energy. Energ Policy, 31, 799-812. https://doi.org/10.1016/S0301-4215(02)00133-7

Messaoudani, Z. L., Rigas, F., Hamid, M. D. B. and Hassan, C. R. C. (2016). Hazards, safety and knowledge gaps on hydrogen transmission via natural gas grid: A critical review. Int $J$ Hydrogen Energ, 41(39), $17511-17525$. https://doi.org/10.1016/j.ijhydene.2016.07.171

Milenić, D., Vasiljević, P. and Vranješ, A. (2010). Criteria for use of groundwater as renewable energy source in geothermal heat pump systems for building heating/cooling purposes. Energ Buildings, 42(5), 649-657. https://doi.org/10.1016/j.enbuild.2009.11.002

Muradov, N. Z. and Veziroglu, T. N. (2008). "Green" path from fossil-based to hydrogen economy: An overview of carbon-neutral technologies. Int J Hydrogen Energ, 33(23), 6804-6839. https://doi.org/10.1016/j.ijhydene.2008.08.054

Nair, N. K. C. and Garimella, N. (2010). Battery energy storage systems: assessment for small-scale renewable energy integration. Energ Buildings, 42(11), 2124-2130. https://doi.org/10.1016/j.enbuild.2010.07.002

Narayanan, A., Mets, K., Strobbe, M. and Develder, C. (2019). Feasibility of 100\% renewable energy-based electricity production for cities with storage and flexibility. Renew Energ, 134, 698-709. https://doi.org/10.1016/j.renene.2018.11.049

Nathan, G. J., Jafarian, M., Dally, B. B., Saw, W. L., Ashman, P. J., Hu, E. and Steinfeld, A. (2018). Solar thermal hybrids for combustion power plant: A growing opportunity. Progress in Energy and Combustion Science, 64, 4-28. https://doi.org/10.1016/j.pecs.2017.08.002

Nayebossadri, S., Speight, J. D. and Book, D. (2019). Hydrogen separation from blended natural gas and hydrogen by Pd-based membranes. Int J Hydrogen Energ, 44(55), 29092-29099. https://doi.org/10.1016/j.ijhydene.2019.03.044

Noorollahi, Y., Saeidi, R., Mohammadi, M., Amiri, A. and Hosseinzadeh, M. (2018). The effects of ground heat exchanger parameters changes on geothermal heat pump performance - A review. Applied Thermal Engineering, 129, $1645-1658$. https://doi.org/10.1016/j.applthermaleng.2017.10.111

Ogden, J., Jaffe, A. M., Scheitrum, D., McDonald, Z. and Miller, M. (2018). Natural gas as a bridge to hydrogen transportation fuel: Insights from the literature. Energy Policy, 115, 317-329. https://doi.org/10.1016/j.enpol.2017.12.049

Olsthoorn, D., Haghighat, F. and Mirzaei, P. A. (2016). Integration of storage and renewable energy into district heating systems: A review of modelling and optimization. Solar Energy, 136, 49-64. https://doi.org/10.1016/j.solener.2016.06.054

Omer, A. M. (2008). Ground-source heat pumps systems and applications. Renew Sust Energ Rev, $12(2), 344-371$. https://doi.org/10.1016/j.rser.2006.10.003

Østergaard, P. A., Duic, N., Noorollahi, Y., Mikulcic, H. and Kalogirou, S. (2020). Sustainable development using renewable energy technology. Renew Energ, 146, 2430-2437. https://doi.org/10.1016/j.renene.2019.08.094

Ouedraogo, N. S. (2019). Opportunities, barriers and issues with renewable energy development in Africa: A comprehensible review. Current Sustainable/Renewable Energy Reports, 6, 52-60. https://doi.org/10.1007/s40518-019-00130-7

Owusu, P. A. and Asumadu-Sarkodie, S. (2016). A review of renewable energy sources, sustainability issues and climate change mitigation. Cogent Engineering, 3, 1167990. https://doi.org/10.1080/23311916.2016.1167990

Pant, D., Van Bogaert, G., Diels, L. and Vanbroekhoven, K. (2010). A review of the substrates used in microbial fuel cells (MFCs) for sustainable energy production. Bioresource Technol, 101, 1533-1543. https://doi.org/10.1016/j.biortech.2009.10.017

Panwar, N. L., Kaushik, S. C. and Kothari, S. (2011). Role of renewable energy sources in environmental protection: A review. Renew Sust Energ Rev; 15(3), 1513-1524. https://doi.org/10.1016/j.rser.2010.11.037

Parida, B., Iniyan, S. and Goic, R. (2011). A review of solar photovoltaic technologies. Renew Sust Energ Rev, 15(3), $1625-1636$. https://doi.org/10.1016/j.rser.2010.11.032

Paska, J., Biczel, P. and Kłos, M. (2009). Hybrid power systems - an effective way of utilising primary energy sources. Renew Energ, 34(11), 2414-2421. https://doi.org/10.1016/j.renene.2009.02.018

Pelay, U., Luo, L., Fan, Y., Stitou, D. and Rood, M. (2017). Thermal energy storage systems for concentrated solar power plants. Renew Sust Energ Rev, 79, 82-100. https://doi.org/10.1016/j.rser.2017.03.139

Pelc, R. and Fujita, R. M. (2002). Renewable energy from the ocean. Mar Policy, 26(6), 471-479. https://doi.org/10.1016/S0308597X(02)00045-3

Pepermans, G., Driesen, J., Haeseldonckx, D., Belmans, R. and D’haeseleer, W. (2005). Distributed generation: definition, benefits and issues. Energ Policy, 33, 787-798. https://doi.org/10.1016/j.enpol.2003.10.004

Perry, S., Kleme`s, J. and Bulatov, I. (2008). Integrating waste and renewable energy to reduce the carbon footprint of locally integrated energy sectors. Energy, 33(10), 1489-1497. https://doi.org/10.1016/j.energy.2008.03.008 
Popovski, E., Fleiter, T., Santos, H., Leal, V. and Fernandes, E. O. (2018). Technical and economic feasibility of sustainable heating and cooling supply options in southern European municipalities-A case study for Matosinhos, Portugal. Energy, 153, 311-323. https://doi.org/10.1016/j.energy.2018.04.036

Pöschl, M., Ward, S. and Owende, P. (2010). Evaluation of energy efficiency of various biogas production and utilization pathways. Appl Energ, 87, 3305-3321. https://doi.org/10.1016/j.apenergy.2010.05.011

Prieto, C., Cooper, P., Inés Fernández, A. and Cabeza, L. F. (2016). Review of technology: Thermochemical energy storage for concentrated solar power plants. Renew Sust Energ Rev, 60, 909-929. https://doi.org/10.1016/j.rser.2015.12.364

Qi, Z., Gao, Q., Liu, Y., Yan, Y. Y. and Spitler, J. D. (2014). Status and development of hybrid energy systems from hybrid ground source heat pump in China and other countries. Renew Sust Energ Rev, 29, 37-51. https://doi.org/10.1016/j.rser.2013.08.059

Rahman, M. M. and Velayutham, E. (2020). Renewable and non-renewable energy consumption-economic growth nexus: New evidence from South Asia. Renew Energ, 147(1), 399-408. https://doi.org/10.1016/j.renene.2019.09.007

Reddy, V. S., Kaushik, S. C., Ranjan, K. R. and Tyagi, S. K. (2013). State-of-the-art of solar thermal power plants-a review. Renew Sust Energ Rev, 27, 258-273. https://doi.org/10.1016/j.rser.2013.06.037

Ren, J., Musyoka, N. M., Langmi, H. W., Mathe, M. and Liao, S. (2017). Current research trends and perspectives on materials-based hydrogen storage solutions: A critical review. Int J Hydrogen Energ, 42(1), $289-311$. https://doi.org/10.1016/j.ijhydene.2016.11.195

Rezaie, B. and Rosen, M. A. (2012). District heating and cooling: Review of technology and potential enhancements. Appl Energ, 93, 2-10. https://doi.org/10.1016/j.apenergy.2011.04.020

Romero, E., Novoderezhkin, V. I. and van Grondelle, R. (2017). Quantum design of photosynthesis for bio-inspired solar-energy conversion. Nature, 543(7645), 355. https://doi.org/10.1038/nature22012

Rosen, M. A. (2009). Energy sustainability: a pragmatic approach and illustrations. Sustainability, 1(1), 55-80. https://doi.org/10.3390/su1010055

Rosen, M. A. (2012). Energy sources: natural versus additional. Article in Jorgensen. S.E. (Ed.). Encyclopedia of Environmental Management, Vol. II, New York: Taylor \& Francis (Book Chapter).

Rosen, M. A. and Koohi-Faegh, S. (2016a). The prospects for hydrogen as an energy carrier: an overview of hydrogen energy and hydrogen energy systems. Energy, Ecology and Environment, 1(1), 10-29. https://doi.org/10.1007/s40974-016-0005-z

Rosen, M. A. and Koohi-Fayegh, S. (2016b). Cogeneration and district energy systems: modelling, analysis and optimization. The Institution of Engineering and Technology. https://doi.org/10.1049/PBPO093E

Rosen, M. A., Dincer, I. and Kanoglu, M. (2008). Role of exergy in increasing efficiency and sustainability and reducing environmental impact. Energ Policy, 36, 128-137. https://doi.org/10.1016/j.enpol.2007.09.006

Rusman, N. A. A. and Dahari, M. (2016). A review on the current progress of metal hydrides material for solid-state hydrogen storage applications. Int J Hydrogen Energ, 41(28), 12108-12126. https://doi.org/10.1016/j.ijhydene.2016.05.244

Saidur, R., Islam, M. R., Rahim, N. A. and Solangi, K. H. (2010). A review on global wind energy policy. Renew Sust Energ Rev, 14(7), 1744-1762. https://doi.org/10.1016/j.rser.2010.03.007

Schenk, P. M., Thomas-Hall, S. R., Stephens, E., Marx, U. C., Mussgnug, J. H., Posten, C., Kruse, O. and Hankamer, B. (2008). Second generation biofuels: high-efficiency microalgae for biodiesel production. BioEnergy Research, 1, 20-43. https://doi.org/10.1007/s12155-008-9008-8

Schmidt, D., Kallert, A., Blesl, M., Svendsen, S., Li, H., Nord, N. and Sipilä, K. (2017). Low Temperature District Heating for Future Energy Systems. Energy Procedia, 116, 26-38. https://doi.org/10.1016/j.egypro.2017.05.052

Sener, C. and Fthenakis, V. (2014). Energy policy and financing options to achieve solar energy grid penetration targets: accounting for external costs. Renew Sust Energ Rev, 32(9), 854-868. https://doi.org/10.1016/j.rser.2014.01.030

Shivarama Krishna, K. and Sathish Kumar, K. (2015). A review on hybrid renewable energy systems. Renew Sust Energ Rev, 52, 907916. https://doi.org/10.1016/j.rser.2015.07.187

Solangi, K. H., Islam, M. R., Saidur, R., Rahim, N. A. and Fayaz, H. (2011). A review on global solar energy policy. Renew Sust Energ Rev, 15, 2149-2163. https://doi.org/10.1016/j.rser.2011.01.007

Soltani, S., Mahmoudi, S. M. S., Yari, M. and Rosen, M. A. (2013). Thermodynamic analyses of a biomass integrated fired combined cycle. Appl Therm Eng, 59(1-2), 60-68. https://doi.org/10.1016/j.applthermaleng.2013.05.018

Stehly, T., Beiter, P., Heimiller, D. and Scott, G. (2017). 2017 Cost of Wind Energy Review. CO: National Renewable Energy Laboratory. NREL /TP-5000-52920. https://doi.org/10.2172/1475534

Stougie, L., Giustozzi, N., van der Kooi, H. and Stoppato, A. (2018). Environmental, economic and exergetic sustainability assessment of power generation from fossil and renewable energy sources. Int J Energy Res, 42, $2916-2926$. https://doi.org/10.1002/er.4037

Tegen, S., Hand, M., Maples, B. and Lantz, E. (2010). 2010 Cost of Wind Energy Review. CO: National Renewable Energy Laboratory. Report NREL/TP-6A20-72167.

Tian, Y. and Zhao, C. Y. (2013). A review of solar collectors and thermal energy storage in solar thermal applications. Appl Energ, 104, 538-553. https://doi.org/10.1016/j.apenergy.2012.11.051 
Toledo, O. M., Filho, D. O. and Diniz, A. S. A. C. (2010). Distributed photovoltaic generation and energy storage systems: a review. Renew Sust Energ Rev, 14, 506-511. https://doi.org/10.1016/j.rser.2009.08.007

Tsoutsos, T., Frantzeskaki, N. and Gekas, V. (2005). Environmental impacts from the solar energy technologies. Energ Policy, 33, 289-296. https://doi.org/10.1016/S0301-4215(03)00241-6

Turner, J., Sverdrup, G., Mann, M. K., Maness, P. C., Kroposki, B., Ghirardi, M., Evans, R. J. and Blake, D. (2008). Renewable hydrogen production. Int J Energ Res, 32, 379-407. https://doi.org/10.1002/er.1372

Uduman, N., Qi, Y., Danquah, M. K., Forde, G. M. and Hoadley, A. (2010). Dewatering of microalgal cultures: a major bottleneck to algae-based fuels. J Renew Sust Energ, 2, 012701. https://doi.org/10.1063/1.3294480

Unique challenges in harnessing open ocean marine hydrokinetic energy. IEEE, OCEANS 2017 - Anchorag, Anchorage, AK, 2017, pp. 1-6.

Ursua, A., Gandia, L. M. and Sanchis, P. (2012). Hydrogen production from water electrolysis: current status and future trends. In proceedings of: the IEEE, 100(2), 410-426. https://doi.org/10.1109/JPROC.2011.2156750

US Department of Energy, Alternative Fuels Data Centre. (n.d.). Available at: https://afdc.energy.gov/ (Accessed 19 May 2020).

van der Heijde, B., Vandermeulen, A., Salenbien, R. and Helsen, L. (2019). Representative days selection for district energy system optimisation: a solar district heating system with seasonal storage. Appl Energ, 248, 79-94. https://doi.org/10.1016/j.apenergy.2019.04.030

Varbanov, P. S. and Klemeš, J. J. (2010). Total sites integrating renewables with extended heat transfer and recovery. Heat Transfer Eng, 31(9), 733-741. https://doi.org/10.1080/01457630903500858

Varun, Prakash, R. and Bhat, I. K. (2009). Energy, economics and environmental impacts of renewable energy systems. Renew Sust Energ Rev, 13, 2716-2721. https://doi.org/10.1016/j.rser.2009.05.007

von Colbe, J. B., Ares, J. R., Barale, J., Baricco, M., Buckley, C., Capurso, G., et al. (2019). Application of hydrides in hydrogen storage and compression: Achievements, outlook and perspectives. Int J Hydrogen Energ, 44(15), 7780-7808. https://doi.org/10.1016/j.ijhydene.2019.01.104

Wang, C. M., Yee, A. A., Krock, H. and Tay, Z. Y. (2011). Research and developments on ocean thermal energy conversion. The IES J, Part A, 4(1), 41-52. https://doi.org/10.1080/19373260.2011.543606

Wang, K., Yuan, B., Ji, G. and Wu, X. (2018a). A comprehensive review of geothermal energy extraction and utilization in oilfields. Journal of Petroleum Science and Engineering, 168, 465-477. https://doi.org/10.1016/j.petrol.2018.05.012

Wang, M., Jing, R., Zhang, H., Meng, C., Li, N. and Zhao, Y. (2018b). An innovative Organic Rankine Cycle (ORC) based Ocean Thermal Energy Conversion (OTEC) system with performance simulation and multi-objective optimization. Applied Thermal Engineering, 145, 743-754. https://doi.org/10.1016/j.applthermaleng.2018.09.075

Wang, Y., Suzuki, H., Xie, J., Tomita, O., Martin, D. J., Higashi, M., Kong, D., Abe, R. and Tang, J. (2018c). Mimicking natural photosynthesis: solar to renewable $\mathrm{H} 2$ fuel synthesis by z-scheme water splitting systems. Chem. Rev., 118(10), 5201-5241. https://doi.org/10.1021/acs.chemrev.7b00286

Wilson, D. G. (2012). Energy supplies and future engines for land, sea, and air. J Air Waste Ma, 62(6), 607-624. https://doi.org/10.1080/10962247.2012.675403

Wüstenhagen, R., Wolsink, M. and Bürer, M. J. (2007). Social acceptance of renewable energy innovation: an introduction to the concept. Energ Policy, 35(5), 2683-2691. https://doi.org/10.1016/j.enpol.2006.12.001

Xu, B., Li, P. and Chan, C. (2015). Application of phase change materials for thermal energy storage in concentrated solar thermal power plants: A review to recent developments. Appl Energ, 160, 286-307. https://doi.org/10.1016/j.apenergy.2015.09.016

Yang, H., Cui, P. and Fang, Z. (2010). Vertical-borehole ground-coupled heat pumps: A review of models and systems. Appl Energ, 87(1), 16-27. https://doi.org/10.1016/j.apenergy.2009.04.038

Yang, H., Wei, Z. and Chengzhi, L. (2009). Optimal design and techno-economic analysis of a hybrid solar-wind power generation system. Appl Energ, 86(2), 163-169. https://doi.org/10.1016/j.apenergy.2008.03.008

Yang, P., Liu, K., Chen, Q., Li, J., Duan, J., Xue, G., Xu, Z., Xie, W. and Zhou, J. (2017). Solar-driven simultaneous steam production and electricity generation from salinity. Energy Environ. Sci., 10, 1923-1927. https://doi.org/10.1039/C7EE01804E

Yaqoot, M., Diwan, P. and Kandpal, T. C. (2016). Review of barriers to the dissemination of decentralized renewable energy systems. Renew Sust Energ Rev, 58, 477-490. https://doi.org/10.1016/j.rser.2015.12.224

Yilanci, A., Dincer, I. and Ozturk, H. K. (2009). A review on solar-hydrogen/fuel cell hybrid energy systems for stationary applications. Prog Energ Combust, 35, 231-244. https://doi.org/10.1016/j.pecs.2008.07.004

Yip, N. Y., Brogioli, D., Hamelers, H. V. M. and Nijmeijer, K. (2016). Salinity gradients for sustainable energy: primer, progress, and prospects. Environ Sci Technol, 50(22), 12072-12094. https://doi.org/10.1021/acs.est.6b03448

Yoon, J. I., Seol, S. H., Son, C. H., Jung, S. H., Kim, Y. B., Lee, H. S., Kim, H. J. and Moon, J. H. (2017). Analysis of the high-efficiency EP-OTEC cycle using R152a. Renew Energ, 105, 366-373. https://doi.org/10.1016/j.renene.2016.12.019

Zabihian, F. and Fung, A. S. (2011). Review of marine renewable energies: case study of Iran. Renew Sust Energ Rev, 15, $2461-2474$. https://doi.org/10.1016/j.rser.2011.02.006

Zeng, X., Ma, Y. and Ma, L. (2007). Utilization of straw in biomass energy in China. Renew Sust Energ Rev, 11, $976-987$. https://doi.org/10.1016/j.rser.2005.10.003 
Zhao, H., Wu, Q., Hu, S., Xu, H. and Rasmussen, C. N. (2015). Review of energy storage system for wind power integration support. Appl Energ, 137, 545-553. https://doi.org/10.1016/j.apenergy.2014.04.103 